\title{
Competition in the Brazilian Loan Market: An Empirical Analysis
}

\author{
- Claudio R. Lucinda*
}

\begin{abstract}
Resumo
Neste artigo, o objetivo é rever os testes empíricos existentes para o grau de competição no setor bancário brasileiro, assim como propor algumas alternativas. Após a descrição do ambiente institucional do sistema bancário brasileiro, os testes sobre a competição, presentes na literatura, foram revisados, começando com o proposto por Panzar e Rosse (1987). A principal conclusão que pode ser extraída desta análise é que o mercado não aparenta estar em equilíbrio de longo prazo, indicando que o mercado não é regido por condições de colusão perfeita. O passo seguinte foi tentar uma nova metodolodia aplicada por Moreno, Martínez e Ruiz (2006) para o mercado bancário espanhol. Nesta metodologia, em que a hipótese de igualdade dos parâmetros de conduta entre empresas e ao longo do tempo é relaxada, os resultados indicam que, para algumas empresas e em alguns instantes do tempo, uma conduta coo-perativa está presente.
\end{abstract}

\section{Palavras-Chave}

competição bancária

\begin{abstract}
The aim of this paper is to review some of the existing tests for competition in Brazilian banking, as well as to propose an alternative. After the description of the institutional setting of the Brazilian Banking system on this period, the competition tests on the literature were reviewed, beginning with the test proposed by Panzar and Rosse (1987). The market does not seem to be in long-run equilibrium, implying only the market does not seem to find itself in collusive outcome. The next step was to try a new methodology, applied by Moreno, Martínez and Ruiz (2006) for the Spanish banking market. On this methodology, in which the assumption of equality of conduct parameters between firms and time periods is relaxed, the results indicate that, for some firms and in some time periods, a cooperative conduct in fact is present.
\end{abstract}

\section{Keywords}

banking competition

\section{JEL Classification}

\author{
L13, L1 1
}

\footnotetext{
* Faculdade de Economia, Administração e Contabilidade de Ribeirão Preto, Universidade de São Paulo (FEARP/USP). E-mail: claudiolucinda@fearp.usp.br.

Contact address: Av. Bandeirantes, 3900 - Monte Alegre - Ribeirão Preto - ZIP 14040-900.

(Recebido em fevereiro de 2009. Aceito para publicação em setembro de 2010).
} 


\section{Introduction}

Since the Real Stabilization Plan of July 1994, one of the most important research questions facing the academic community is about the interest rate charged by the bakning system. As of March 2010, from an interest rate of about $8.75 \%$ per annum on Brazilian Treasury bonds, the lending interest rate reaches from 30.45\% p.a. in the case of Working Capital Loans, to $161.05 \%$ p.a. in the case of overdraft accounts to individuals. Furthermore, the data also show the Brazilian economy is characterized by a low degree of financial intermadiation. According to Belaisch (2003), the Brazilian banking system is surprisingly small, compared to industrialized economies. The importance of these stylized facts was not left unattended of the professional academic community in Brazil, the literature on this subject is growing steadily, and can be categorized on three strands. The first one emphasizes the role of institutional elements on the lending rates' spread over the risk-free rates. Some of the most important elements singled out for analysis are:

- The role the tax code currently plays on the intermediation spread between lending and borrowing. On this subject, Cardoso and Koyama (2000) report on taxes and contributions currently levied on the lending operations by banks, which were then responsible for approximately $17,1 \%$ of the lending rate on a two month lending operation for a company.

- The reduced creditor protection offered by Brazilian law, associated with the high levels of non-performing credits on the portfolios of banks. The same study of Cardoso and Koyama (2000) also indicates the high amount of non-performing loans increases significantly the spread, which can only be reduced by increased credit information and improvements on creditors' rights. This line of reasoning is also present on papers by Costa (2004) and Costa and Nakane (2004).

The second line of study enphasizes efficiency aspects of the banking sector. In doing so, they investigate the role some factors play on technical efficiency - understood as the distance from an hypothetical efficient technical frontier - of Brazilian banking sector. A subsidiary line of research is preocuppied with potential productivity differences between private and state-owned banks. Some papers are Nakane (1999) and Silva and Jorge Neto (2002). Belaisch (2003) indicates that operating expenses account for about $90 \%$ of operating income in Brazil, thirty percentage points above the figure recorded for the other large Latin American countries. 
Finally, the last line of research enphasizes the role of competition on the determination of spreads. On this subject, Belaisch (2003)used a panel database to conclude that the behavior of a sample of Brazilian banks is not consistent with a competitive market structure. Other important papers on the subject are Nakane (2001, 2004), and Petterini and Jorge Neto (2003), which use econometric techniques to determine if the behavior of Brazilian banks is consistent with some alternative competition structures.

Petterini and Jorge Neto (2003) use a version of the model by Jaumandreu and Lorences (2002), and conclude for the rejection of the collusive hypothesis on the Brazilian banking industry. A two step approach was used, in which are estimated demand equations in a first step in order to obtain the relevant own and cross price elasticities. Given those elasticities, the results corresponding to differing equilibria are computed and a model selection test statistic is used for selecting the behavior not rejected by the evidence presented by the data.

Nakane (2001) uses the methodology presented in Bresnahan (1982) and Lau (1982) to estimate the percentage response of the market supply of loans to a given percentage change on the loan supply of a given bank. The estimated value by Nakane (2001) is significantly different from zero, indicating the rejection of the perfect competition hypothesis. However, the small magnitude of the coefficient, combined with the results of statistical tests, also point out to the rejection of the collusion hypothesis.

Using the Panzar and Rosse (1987) methodology, Belaisch (2003) finds evidence of a non-competitive market strutucture. Araújo et al. (2005) also use this methodology as a stepping stone on their analysis of the effects of market concentration on competition, and also report results consistent with Belaisch's (2003). All these results do have some similarities, for in all of them the hypotheses of a behavior consistent with either extreme of the taxonomy of market strutuctures - perfect competition or monopoly - is rejected by the data. Even though this result does shed some light on the matter, it still does not give evidence on how Brazilian banks compete.

Given this literature, the aim of this paper is to try to establish some characteristics of how Brazilian banks compete, in order to better direct the theoretical efforts to explain Brazilian banking competition. Before that, some historical and institutional characteristics of the Brazilian banking system must be highlighted. This will be detailed on the following section. 


\section{History and Institutional Characteristics of the Brazilian Banking Sector}

In order to better understand the characteristics of the Brazilian banking system one must begin by highlighting the effects of the high inflation environment that was a fixture of the Brazilian economy from the beginning of the eighties to the successful stabilization plan (Real Plan) in 1994. ${ }^{1}$ According to Loyola et al. (2003), the most important characteristics, were:

- Overbranching: the race for deposits in the period of high inflation entailed the opening of a large number of branches, many of which were not profitable after the Real Plan.

- Overbanking: the high inflation period also witnessed the opening of a large number of banking institutions, reaching 250 in 1993, from 121 in 1987.

- Collapse of the long-run credit market: given the high level and variability of the inflation rates, Brazilian banks refrained from their classical functions of channeling credit and financial intermediation.

- High level of investment of information technology and clearing of payments, given the need for a speedy clearing of outstanding inter-bank balances.

After the Real Plan, the sudden decrease on the inflation rates, by reducing the revenues associated with the management of the short-run deposits, exposed some of the operational problems of these institutions. The most affected group was composed of state owned banks, and specially the ones owned by subnational governments, which were used as quasi monetary authorities by the state governors, ${ }^{2}$ as well as a source of political benefits for the incumbent political party. On the second half of the nineties, these practicies had to end, exposing the weak operational performance of such banks. This led to the restructuring of the sector, helped by a program designed by the Federal Government (PROES). ${ }^{3}$

1 One of the most interesting characteristics of the Brazilian inflationary process was the lack of an overt process of dollarization, as in the other Latin American countries during the same period. The agents responded to the high inflation environment by moving their resources to the banking system, which developed a large number of financial instruments intended to protect the real value of money holdings. Despite being interesting, this will not be our aim on this paper, except where it provides a backdrop for some institutional characteristics of the system.

2 Before the Stabilization Plan, the state governors used to finance their expenditures through their banks, which regularly turned insolvent. However, the Federal Government usually ended up bailing out these banks, warranting their use as independent monetary authorities.

3 For its portuguese name, Programa de Incentivo à Redução do Setor Público na Atividade Bancária. 
However, not only the state owned banks found themselves with difficulties after the decrease in inflation rates. For the private owned banks, the federal government also set up a program to ease the restructuring of such banks, denoted PROER. ${ }^{4}$ This program, which made available credit lines for the prospective buyers and allowed the break-up of the troubled banks into two parts, ${ }^{5}$ enabled a relatively quick turnover of the banks affected by the disinflation process. The following table gives some details on the structure and evolution of the banking system:

Table 1 - Brazilian Banking Industry - Selected Indicators

\begin{tabular}{lcccccccc}
\hline & 2001 & 2002 & 2003 & 2004 & 2005 & 2006 & 2007 & 2008 \\
\hline Public & 15 & 15 & 15 & 14 & 14 & 13 & 13 & 12 \\
Private-Domestic & 81 & 76 & 78 & 82 & 82 & 81 & 77 & 78 \\
$\begin{array}{l}\text { Private-Foreign } \\
\text { Participation }\end{array}$ & 14 & 11 & 10 & 10 & 8 & 9 & 10 & 7 \\
$\begin{array}{l}\text { Private-Foreign } \\
\text { Control }\end{array}$ & 75 & 67 & 63 & 59 & 57 & 57 & 59 & 63 \\
Total Private & 170 & 154 & 151 & 151 & 147 & 147 & 146 & 148 \\
Grand Total & 185 & 169 & 166 & 165 & 161 & 160 & 159 & 160 \\
\hline
\end{tabular}

Source: Central Bank of Brazil.

As regards prices of the services offered by the Brazilian Banking System, in January 2010, the spreads over the basic were about 120 to 140 percentage points in the case of overdraft accounts, to less than 40 percentage points for personal credit lines and 20 p.p. to auto credit. For businesses, the spreads seem to be more volatile, ranging from 50 p.p. in discounts of trade notes to less than 10 p.p. in vendor credit. The next step in the analysis is to investigate the nature of the competition on the Brazilian Banking System.

\section{Competition on Brazilian Banking System}

After discussing the institutional characteristics of the Brazilian Banking Sector on the previous one, the empirical evaluation of the behavior of the system is carried out. In order to carry out such a challenge, a database from quarterly balance sheet data from the first quarter of 2000 to the fourth quarter of $2005^{6}$ was assem-

4 In Portuguese, Programa de Estímulo à Reestruturação e ao Fortalecimento do Sistema Financeiro Nacional.

5 The troubled banks were split into two parts. One included the non-performing assets, and was handed over to the Central Bank for recovery of such credits and repayment to the shareholders and some creditors. The second part, which included the portfolio of "good" credits and the deposits, was to be auctioned off.

6 The data was obtained from the website of the Brazilian Central bank: <http://www.bcb.gov.br/ Fis/Top50/Port/default-i.asp?idioma $=I \& i d=50$ top $>$. 
bled. For each of the banks, data on assets, liabilities and net profit statement was collected, and the relevant variables for the econometric analysis that follows are constructed. The definition of the variables is presented below, and the descriptive statistics are presented on the Appendix A.

\section{Table 2 - Variable Definitions}

\begin{tabular}{|c|c|c|}
\hline $\begin{array}{l}\text { Variable } \\
\text { Code }\end{array}$ & Meaning & $\begin{array}{l}\text { Construction - Numbers refer to account codes at } \\
\text { the COSIF system }\end{array}$ \\
\hline$v 7$ & Total Assets & $10000007(+)$ and $20000004(+)$ \\
\hline$v 13$ & Loans and Leases - Total & $\begin{array}{l}16000001(+), 16900008(-), 17000000(+) \text { and } \\
17900007(-)\end{array}$ \\
\hline$v 14$ & Provision for Non-Performing & $16900008(+), 17900007(+)$ \\
\hline$v 17$ & Leased Assets & $23000001(+)$ \\
\hline$v 18$ & Fixed Assets & $20000004(+), 23000001(-)$ \\
\hline$p 7$ & Total Liabilities & $40000008(+), 50000005(+)$ \\
\hline$p 13$ & Total Deposits & $41000007(+)$ \\
\hline$p 18$ & Liabilities on Loans & $46000002(+)$ \\
\hline$d 13$ & Total Deposits & $41000007(+)$ \\
\hline 17 & Service Charges & $71700009(+)$ and $71970004(+)$ \\
\hline 18 & Payroll Expenses & $\begin{array}{l}81718005(+), 81727003(+), 81730007(+), \\
81733004(+), 81736001(+), 81737000(+), \\
81990201(+)\end{array}$ \\
\hline 19 & Overhead & $\begin{array}{l}81703003(+), 81706000(+), 81709007(+), \\
81712001(+), 81715008(+), 81721009(+), \\
81724006(+), 81739008(+), 81742002(+), \\
81745009(+), 81748006(+), 81751000(+), \\
81754007(+), 81757004(+), 81760008(+), \\
81763005(+), 81766002(+), 81772003(+), \\
81775000(+), 81777008(+), 81781001(+), \\
81799000(+), 81810006(+), 81820003(+) \text { and } \\
81990304(+)\end{array}$ \\
\hline$l 10$ & Tax Expenses & $\begin{array}{l}81769009(+), 81925001(+), 81930003(+) \\
81933000(+) \text { and } 81990902(+)\end{array}$ \\
\hline$l 12$ & Other Operating Revenues & $\begin{array}{l}71930006(+), 71975009(+), 71985006(+), 71990950 \\
(+), 71990998(+) \text { and } 71999009(+)\end{array}$ \\
\hline$l 13$ & Other Operating Expenses & $\begin{array}{l}81830990(+), 81910009(+), 81920006(+), \\
81936007(+), 81952005(+), 81965009(+), \\
81975006(+), 81985003(+), 81990108(+) \text { and } \\
81999006(+)\end{array}$ \\
\hline$l 15$ & Non-Operating Income & $73000006(+)$ and $83000003(+)$ \\
\hline 120 & Number of Workers & \\
\hline 121 & Number of Branches & \\
\hline$r 7$ & Loans and Leases (Revenues) & $\begin{array}{l}71100001(+), 71200004(+), 71920009(+), \\
71925004(+), 71950000(+), 71980001(+), \\
81940000(+), 81945005(+) \text { and } 81950007(+)\end{array}$ \\
\hline
\end{tabular}




\begin{tabular}{|c|c|c|}
\hline $\begin{array}{l}\text { Variable } \\
\text { Code }\end{array}$ & Meaning & $\begin{array}{l}\text { Construction - Numbers refer to account codes at } \\
\text { the COSIF system }\end{array}$ \\
\hline$r 8$ & Repo-Resell (Revenues) & $\begin{array}{l}71400000(+), 71500003(+), 71580009(-), \\
71940003(+), 71945008(+), 71947006(+), \\
71990053(+), 71990101(+), 71990156(+), \\
71990204(+), 71990709(+), 81500000(+), \\
81550005(-), 81830055(+), 81830103(+), \\
81830158(+), 81830206(+) \text { and } 81830701(+)\end{array}$ \\
\hline$r 9$ & Derivative Financial Instruments (Revenues) & $\begin{array}{l}71580009(+), 81550005(+), 71990266(+) \text { and } \\
81830268(+)\end{array}$ \\
\hline$r 10$ & Foreign Exchange (Revenues) & 71300007 (+) and 81400007 (+) (if positive) \\
\hline$r 11$ & Required Deposits (Revenues) & $\begin{array}{l}71955005(+), 71960007(+), 71965002(+), \\
71990125(+) \text { and } 81830127(+)\end{array}$ \\
\hline$r 12$ & $\begin{array}{l}\text { Deposits, Acceptances and Repo-Repurchases } \\
\text { (Expenses) }\end{array}$ & $81100008(+)$ and $81980008(+)$ \\
\hline$r 13$ & Borrowing (Expenses) & $81200001(+)$ and $81960004(+)$ \\
\hline$r 14$ & Lease (Expenses) & $\begin{array}{l}71990503(+), 81300004(+), 81830505(+) \text { and } \\
81830550(+)\end{array}$ \\
\hline$r 15$ & Exchange Rate Operations (Expenses) & $71300007(+)$ and 81400007 (+) (if negative) \\
\hline$r 16$ & Allowance for Bad Credits & $\begin{array}{l}71990307(+), 71990352(+), 71990400(+), \\
71990606(+), 81830309(+), 81830354(+), \\
81830402(+) \text { and } 81830608(+)\end{array}$ \\
\hline TOTAL $L_{i t}$ & \multicolumn{2}{|c|}{ Total Number of Branches in the System (Per Quarter) } \\
\hline$A G N_{i t}$ & Share of Total Number of Branches & l21/TOTAL $L_{i t}$ \\
\hline$C R D_{i t}$ & Risk on Financial Intermediation & $v 13 /(d 13+p 18)$ \\
\hline$W 1_{i t}$ & Payments to the Labor Force & $(-18 / l 20)$ \\
\hline$R D E P_{i t}$ & Remuneration to deposits & $((-1) *(r 12+r 13+r 14+r 15+l 13)) /(p 7+p 13)$ \\
\hline$W 3_{i t}$ & Remuneration fo Physical Capital & $(-l 9) /(v 17+v 18)$ \\
\hline$R T_{i t}$ & Total Revenue & $(r 7+r 8+r 9+r 10+r 11+17+112+115)$ \\
\hline$D E P S_{i t}$ & Total Deposits & $(p 7+p 13)$ \\
\hline$Y_{i t}$ & GDP at Market Prices (Source:IPEA) & \\
\hline$Q_{i t}$ & Total Assets & $v 7$ \\
\hline$P_{i t}$ & Ratio of Annual Interest Income to Total Assets & $(r 7+r 8+r 9+r 10+r 11) / \mathrm{v} 7$ \\
\hline$Z_{i t}$ & \multicolumn{2}{|c|}{ Interbank Rate - Per Quarter (Source: IPEA and transformation to per quarter) } \\
\hline$N P_{i t}$ & Share of Non-Performing Assets & $(-1)^{*}(\mathrm{v} 14 / \mathrm{v} 7)$ \\
\hline QUALit & Measure of Quality of services & $120 / 121$ \\
\hline$C_{i t}$ & Total Costs & $\begin{array}{l}(-1)^{*}(18+l 9+l 10+l 13+r 12+r 13+r 14+ \\
r 15+r 16)\end{array}$ \\
\hline$C R E D S_{i t}$ & Total Credits & $v 8+v 9+\mathrm{v} 10+\mathrm{v} 13+v 15$ \\
\hline$R C R E D_{i t}$ & Remuneration to credits & $(r 7+r 8+r 9+r 10+r 11+l 7+l 12) / C R E D S_{i t}$ \\
\hline$S H A R E_{i t}$ & Market Share in Credits & \\
\hline$C R 3_{i t}$ & Sum of the three largest market shares & \\
\hline $\operatorname{ASSEMP}_{i t}$ & Assets per Employee & $v 7 / 120$ \\
\hline$S U 1_{i t}$ & $\begin{array}{l}\text { Share of Remuneration of Employees in Total } \\
\text { Cost }\end{array}$ & $(-1)^{*}(18) / C_{i t}$ \\
\hline$S U 2_{i t}$ & $\begin{array}{l}\text { Share of Remuneration of Physical Capital in } \\
\text { Total Cost }\end{array}$ & $(-1)^{*}(19) / C_{i t}$ \\
\hline
\end{tabular}


A definite conclusion on how Brazilian banks compete must require answers to some questions before any econometric test is carried out. One of the most important questions is about the definition of the relevant variables, since there is some disagreement on what consititute inputs and outputs of the banking activity. For instance, in some papers the deposits are considered as an input for the production of the output - as in the "Monti-Klein" model of financial intermediation. ${ }^{7}$ In others, both credits and deposits are services to be considered as outputs to be offered in joint production. In order to consider all possibilities, we will adopt an ecletic approach, allowing both possibilities. ${ }^{8}$

As for the methodological approaches followed here, we chose options based on the estimation of conduct parameter - either directly or as a measure that can bem mapped in the conduct parameter such as Panzar and Rosse (1987). Alternative approaches, such as of the non-nested hypothesis favored by Nevo (1998) are not possible because of the lack of avaliable data.

\subsection{The Panzar-Rosse Methodology}

For analyzing Brazilian banking competition, the first econometric test is based on the general methodology proposed by Panzar and Rosse (1987) for what they call "monopoly equilibrium". On that paper, they start from the comparative statics of a firm's equilibrium under alternative competition assumptions. From that point on, they derive conclusions on the sum of the elasticities of the total revenue with respect to the prices of each of the productive factors, which they denote $\psi$ and the following literature calls the "Statistic H of Panzar and Rosse". The conclusions are stated as follows:

- Theorem 1 (Panzar and Rosse, 1987, p. 445): "The sum of the factor price elasticities of a monopolist's reduced form revenue equation ${ }^{9}$ must be nonpositive." (thus, $\psi \leq 0$ ).

- Proposition 1 (Panzar and Rosse, 1987, p. 451): "In symmetric Chamberlinian equilibrium, the sum of the elasticities of firm's reduced form revenues with respect to factor prices is less than or equal to unity." (thus, $\psi \leq 1$ ).

7 It is important to notice, though, the assumption of deposits as an independent product does not imply the deposits of an individual bank cannot be used to increase the supply of an individual bank. The deposits, even though they are considered a service provided to its customers, are used to finance the interbank market which is the source of all loans. An useful reference is Freixas and Rochet (1997), p. 55.

8 The financial institutions selected were both commercial banks, which were able to finance themselves by deposits and investment banks, which were not.

9 Reduced form revenue equation means the equation on which the total revenue is a function of only variables whose values are considered to be exogenous to the bank's decision. 
- Proposition 2 (Panzar and Rosse, 1987, p. 452): "For firms observed in long-run competitive equilibrium, the sum of the elasticities of reduced form revenues with respect to factor prices equals unity." (thus, $\psi=1$ ).

The meaning of Proposition 2 could be interpreted as follows (SHAFFER, 2004): in an industry in the long-run competitive equilibrium, all firms are operating at the minimum efficient scale. In response to a given increase on input prices, and supposing the cost function to be homogeneous of degree one in factor prices, the average cost increase will be by the same percentage amount as the original increase in input prices. This change in the cost function will lead to entry or exit, giving way to a different equilibrium. On this new equilibrium, the quantity demanded is unchanged, but the price is not; since companies are producing at the minimum average cost on the new cost curve, this means the revenues have increased by the same amount. Thus, the effect of an increase in input prices is to bring about an increase in total revenue by the same percentage amount.

The Theorem 1 could be understand as follows: in a monopoly equilibrium, the quantity supplied is such to equate the marginal revenue to marginal cost. Supposing the marginal cost function homogeneous of degree one again, and the marginal cost curve to intersect the marginal revenue curve from below, the response of a monopolist to an increase in input prices is an increase in marginal cost by the same percentage amount as the increase in factor prices, and a decrease in quantities. Since marginal revenue is always non-negative in equilibrium, this means the total revenue must decrease, implying $\psi \leq 0$.

The authors also try to investigate the behavior of this statistic under the assumption of a conjectural variations oligopoly, but they find out the behavior of $\psi$ on this case to be indeterminate. The only result these authors derive refers to the effect of factor prices on output. ${ }^{10}$

This methodology has been applied in many settings, besides the applications by Araújo et al. (2005) and Belaisch (2003) for the Brazilian banking. Mathisen and Buchs (2005) also apply it for the Ghanian financial system, Prasad and Ghosh (2005) do the same for the Indian Banking system, Bikker and Raaf (2002) for the the european banking sector, among many others. ${ }^{11}$ Cetorelli (1999) has a short survey of the most important methodologies.

10 They found out the sum of elasticites of factor prices on the reduced form output equation is to be negative

11 In fact, given the large number of papers which use this methodology, one can safely conclude that this is one of the most important methodologies for investigating the degree of competitiveness for any given industry, together with the various versions the of Bresnahan (1982) and Lau (1982) approach. 
However, this methodology is not exempt of problems. The first one is that the results derived by Panzar and Rosse (1987) are found under conditions of long-run equilibrium only. If this condition is not verified in practice, the Panzar and Rosse statistic has its meaning changed. As Shaffer (1983) have pointed out, in the case of short-run equilibrium the test on the $\psi$ statitsic reduces to an one tailed test in which a positive value rejects any form of imperfect competition, and a negative value is consistent with various possible competitive structures. This test of longrun competition is usually carried out by investigating the effects of changes in input prices on profits. Is these are zero, it is assumed the market is in long-run equilibrium.

The second problem is some test results might not discriminate between different market structures. As Panzar and Rosse (1987, p. 451) state after deriving the range of values consistent with the Chamberlinian oligopoly:

The range of permissible values for $\dot{\psi}$ - i.e., the values for the $\mathrm{H}$ statistic consistent with Chamberlinian equilibrium - includes that of $\psi^{*}$ - the values for the $\mathrm{H}$ statistic consistent with Monopoly equilibrium - (i.e., the negative real line) plus the unit interval. Thus the analyst can, in principle, observe data that are consistent with the hypothesis of monopolistic competition but not with that of profit maximizing monopoly.

As Shaffer $(1983,2004)$ also points out, a value for $\psi$ equal to one could be consistent with either a policy of fixed markups or a sales maximization under a break-even constant, or even in a market of local natural monopolies under contestability.

Another criticism comes from Bikker et al. (2006), which conclude the inclusion of scale variables as independent regressors in the Panzar-Rosse test equation tends to bias the $\hat{\psi}$ coefficient upward.

In any case, this methodolgy provides a useful starting point, since this methodology doees not require defining the relevant markets, and our application of the test is based upon the following regression:

$$
\begin{aligned}
& \ln \left(R T_{i t}\right)=\beta_{1} \ln \left(A G N_{i t}\right)+\beta_{2} \ln \left(C R D_{i t}\right)+\beta_{3} \ln \left(D E P S_{i t}\right)+ \\
& +\beta_{4} \ln \left(W 1_{i t}\right)+\beta_{5} \ln \left(R D E P S_{i t}\right)+\beta_{6} \ln \left(W 3_{i t}\right)+f_{i}+\varepsilon_{i t}
\end{aligned}
$$


In which the term $f_{i}$ denotes the individual effect and the Panzar-Rosse $\mathrm{H}$ statistic is $\beta_{4}+\beta_{5}+\beta_{6}$. The $A G N_{i t}$ variable, defined as in Araújo et al. (2005) as the share of bank $i$ in the systemwide number of branches, is related to the "too big to fail" characteristic that some banks present. The $C R D_{i t}$ variable, total loans over the sum of total deposits and liabilities on loans, was intended as a proxy for intermediation risk; and $D E P S_{i t}$, total deposits, tries to capture scale economies.

The $R D E P S_{i t}, W 1_{i t}$ and $W 3_{i t}$ variables are the input prices in this case (deposits, payments to the labor force and remuneration to physical capital), meaning we are implicitly adopting the view of the banking firm as of the "Monti-Klein" model. The results are presented both for the full sample, as well as for sub-samples comprising only commercial banks, investment banks and sub groups sorted according to size (banks with average assets below 250 million Reais, those with assets between 250 and 5,000 and those with average assets above 5,000 million reais). ${ }^{12}$ Another interesting issue ${ }^{13}$ is that many mergers happened during this period. In order to face the effect of these mergers on the results, the estimates were also carried out using only the balanced sample, that is, banks which were present at all time periods in our sample.

12 The smaller group comprises banks associated with retailers, smaller brokerage firms and branches of international groups. The medium sized institutions were banks associated with automakers (such as GM, Volkswagen) and former regional state owned banks. And finally, the largest group comprises the largest private banks, as well as Banco do Brasil and CEF, as well as some of the larger subnational state owned banks.

13 We would like to thank an anonymous referee for this remark. 
Table 3 - Regression Results - Deposits as an Input (Top)

\begin{tabular}{|c|c|c|c|c|c|c|}
\hline & $\begin{array}{c}\text { Full } \\
\text { Sample }\end{array}$ & $\begin{array}{l}\text { Large } \\
\text { Banks }\end{array}$ & $\begin{array}{l}\text { Medium } \\
\text { Banks }\end{array}$ & $\begin{array}{r}\text { Small } \\
\text { Banks }\end{array}$ & $\begin{array}{c}\text { Commercial } \\
\text { Banks }\end{array}$ & $\begin{array}{c}\text { Investment } \\
\text { Banks }\end{array}$ \\
\hline $\ln \left(A G N_{i t}\right)$ & $\begin{array}{c}0.082 \\
(1.730)\end{array}$ & $\begin{array}{c}0.054 \\
(1.254)\end{array}$ & $\begin{array}{c}0.069 \\
(1.802)\end{array}$ & $\begin{array}{c}0.244 \\
(1.983)\end{array}$ & $\begin{array}{c}0.055 \\
(1.203)\end{array}$ & $\begin{array}{c}0.059 \\
(0.660)\end{array}$ \\
\hline $\ln \left(C R D_{i t}\right)$ & $\begin{array}{l}0.066 \text { ** } \\
(2.857)\end{array}$ & $\begin{array}{c}0.007 \\
(0.352)\end{array}$ & $\begin{array}{c}0.055 \\
(1.911)\end{array}$ & $\begin{array}{c}0.028 \\
(0.855)\end{array}$ & $\begin{array}{c}0.078 \\
(1.504)\end{array}$ & $\begin{array}{l}0.058 \text { * } \\
(2.414)\end{array}$ \\
\hline $\ln \left(W 1_{i t}\right)$ & $\begin{array}{l}0.152 \text { * } \\
(2.547)\end{array}$ & $\begin{array}{c}0.023 \\
(1.420)\end{array}$ & $\begin{array}{l}0.197^{* * *} \\
(3.838)\end{array}$ & $\begin{array}{l}0.256 \text { ** } \\
(3.059)\end{array}$ & $\begin{array}{c}0.087 \\
(1.830)\end{array}$ & $\begin{array}{l}0.3088^{* * *} \\
(3.549)\end{array}$ \\
\hline $\ln \left(R D \mathrm{EP}_{i t}\right)$ & $\begin{array}{l}0.623{ }^{* * *} \\
(12.470)\end{array}$ & $\begin{array}{c}0.8022^{* \star *} \\
(42.371)\end{array}$ & $\begin{array}{l}0.712^{* * *} \\
(23.732)\end{array}$ & $\begin{array}{l}0.375^{* \star \star} \\
(7.159)\end{array}$ & $\begin{array}{l}0.744^{* * *} \\
(24.961)\end{array}$ & $\begin{array}{l}0.513^{* * *} \\
(8.317)\end{array}$ \\
\hline $\ln \left(D E P S_{i t}\right)$ & $\begin{array}{l}0.700^{* * \star} \\
(15.064)\end{array}$ & $\begin{array}{l}0.805^{* * *} \\
(23.325)\end{array}$ & $\begin{array}{l}0.811^{* \star *} \\
(36.054)\end{array}$ & $\begin{array}{l}0.327^{\star \star \star \star} \\
(4.983)\end{array}$ & $\begin{array}{c}0.7899^{* * *} \\
(19.170)\end{array}$ & $\begin{array}{l}0.614^{* * *} \\
(10.450)\end{array}$ \\
\hline $\ln \left(W 3_{i t}\right)$ & $\begin{array}{l}0.075 \text { * } \\
(2.524)\end{array}$ & $\begin{array}{l}0.094^{* * *} \\
(5.770)\end{array}$ & $\begin{array}{c}0.043 \\
(1.970)\end{array}$ & $\begin{array}{c}0.127 \\
(1.549)\end{array}$ & $\begin{array}{l}0.083 \text { ** } \\
(3.173)\end{array}$ & $\begin{array}{c}0.058 \\
(0.937)\end{array}$ \\
\hline Constant & $\begin{array}{l}3.841^{* * *} \\
(5.071)\end{array}$ & $\begin{array}{l}3.5466^{* * *} \\
(4.764)\end{array}$ & $\begin{array}{l}2.091^{* * *} \\
(4.245)\end{array}$ & $\begin{array}{l}7.993^{* * *} \\
(5.737)\end{array}$ & $\begin{array}{l}3.111^{* * *} \\
(3.857)\end{array}$ & $\begin{array}{l}3.590{ }^{* *} \\
(3.104)\end{array}$ \\
\hline Number of Obs. & 2458 & 571 & 1396 & 491 & 1332 & 1126 \\
\hline R-sq & 0.844 & 0.954 & 0.918 & 0.743 & 0.896 & 0.815 \\
\hline Panzar's H Stat & 0.850 & 0.920 & 0.952 & 0.758 & 0.913 & 0.879 \\
\hline $\mathrm{H}=1$ ( $\mathrm{p}$-value) & 0.000 & 0.000 & 0.009 & 0.000 & 0.000 & 0.000 \\
\hline $\mathrm{H}=0$ (p-value) & 0.000 & 0.000 & 0.000 & 0.000 & 0.000 & 0.000 \\
\hline & $\begin{array}{c}\text { Full } \\
\text { Sample }\end{array}$ & $\begin{array}{l}\text { Large } \\
\text { Banks }\end{array}$ & $\begin{array}{l}\text { Medium } \\
\text { Banks }\end{array}$ & $\begin{array}{l}\text { Small } \\
\text { Banks }\end{array}$ & $\begin{array}{c}\text { Commercial } \\
\text { Banks }\end{array}$ & $\begin{array}{c}\text { Investment } \\
\text { Banks }\end{array}$ \\
\hline $\ln \left(A G N_{i t}\right)$ & $\begin{array}{l}0.234^{* *} \\
(3.235)\end{array}$ & $\begin{array}{c}0.217 \\
(1.771)\end{array}$ & $\begin{array}{l}0.2422^{* *} \\
(2.825)\end{array}$ & $\begin{array}{c}0.399 \\
(1.473)\end{array}$ & $\begin{array}{c}0.179 \\
(1.822)\end{array}$ & $\begin{array}{c}0.199 \\
(1.309)\end{array}$ \\
\hline $\ln \left(C R D_{i t}\right)$ & $\begin{array}{l}0.105^{* *} \\
(3.037)\end{array}$ & $\begin{array}{l}0.176 \text { ** } \\
(3.057)\end{array}$ & $\begin{array}{c}0.051 \\
(1.516)\end{array}$ & $\begin{array}{l}0.096 \text { * } \\
(2.498)\end{array}$ & $\begin{array}{c}0.078 \\
(1.502)\end{array}$ & $\begin{array}{l}0.092 \text { * } \\
(2.530)\end{array}$ \\
\hline $\ln \left(W 1_{i t}\right)$ & $\begin{array}{l}0.353^{* *} \\
(3.291)\end{array}$ & $\begin{array}{c}0.175 \\
(1.913)\end{array}$ & $\begin{array}{l}0.550^{* \star *} \\
(6.835)\end{array}$ & $\begin{array}{l}0.323 \text { ** } \\
(3.162)\end{array}$ & $\begin{array}{l}0.271^{\star *} \\
(2.683)\end{array}$ & $\begin{array}{l}0.5911^{* \star *} \\
(5.682)\end{array}$ \\
\hline $\ln \left(D E P S_{i t}\right)$ & $\begin{array}{l}0.586^{* * *} \\
(9.913)\end{array}$ & $\begin{array}{l}0.595^{* * *} \\
(3.900)\end{array}$ & $\begin{array}{l}0.596 \\
(11.011)\end{array}$ & $\begin{array}{l}0.350 \text { * } \\
(2.466)\end{array}$ & $\begin{array}{l}0.499 * * * \\
(6.676)\end{array}$ & $\begin{array}{l}0.574^{* * *} \\
(8.490)\end{array}$ \\
\hline $\ln \left(W 3_{i t}\right)$ & $\begin{array}{l}0.144 \text { * } \\
(2.567)\end{array}$ & $\begin{array}{l}0.339^{* * *} \\
(4.159)\end{array}$ & $\begin{array}{c}0.052 \\
(1.279)\end{array}$ & $\begin{array}{l}0.207 \text { * } \\
(2.154)\end{array}$ & $\begin{array}{l}0.193^{* *} \\
(3.141)\end{array}$ & $\begin{array}{c}0.106 \\
(1.337)\end{array}$ \\
\hline Constant & $\begin{array}{l}3.754 \text { ** } \\
(3.314)\end{array}$ & $\begin{array}{c}5.199 \\
(1.629)\end{array}$ & $\begin{array}{l}2.610 \text { * } \\
(2.251)\end{array}$ & $\begin{array}{l}7.487 \text { ** } \\
(2.820)\end{array}$ & $\begin{array}{l}5.274^{* \star *} \\
(3.530)\end{array}$ & $\begin{array}{c}2.301 \\
(1.717)\end{array}$ \\
\hline Number of Obs. & 2458 & 571 & 1396 & 491 & 1332 & 1126 \\
\hline R-sq & 0.534 & 0.557 & 0.593 & 0.561 & 0.505 & 0.590 \\
\hline Panzar's H Stat & 0.497 & 0.515 & 0.602 & 0.529 & 0.464 & 0.697 \\
\hline $\mathrm{H}=1$ (p-value) & 0.000 & 0.000 & 0.000 & 0.000 & 0.000 & 0.000 \\
\hline $\mathrm{H}=0$ (p-value) & 0.000 & 0.000 & 0.000 & 0.000 & 0.000 & 0.000 \\
\hline
\end{tabular}

Obs: Asymptotic t Stats in Parentheses. Codes: P-value $<0.01^{* * *}, \mathrm{P}$-value $<0.05^{* *}$ and $\mathrm{P}$-value $<0.1^{*}$. 
The robust standard errors are in parentheses, and the table points out some interesting results. The first one is all variables are highly significant and the model does present a high explanatory power. And finally, the results for the test of competitive structure point out to a Panzar-Rosse H Statistic of 0.8 , and both hypotheses of $\psi=0$ and $\psi=1$ are rejected, which should point out to a competitive structure of Chamberlinian oligopoly, if the market is shown to be in long-run equilibrium. The results are qualitatively similar for each subsample, in which both hypotheses $\psi=0$ and $\psi=1$ are rejected.

Two other alternatives were tried, in order to face the criticisms posed by Bikker et al. (2006) about the inclusion of scale variables as explanatory variables. In one alternative, the $\ln \left(D E P S_{i t}\right)$ variable was dropped from the estimating equations and in the other alternative both $\ln \left(D E P S_{i t}\right)$ and $\ln \left(A G N_{i t}\right)$ were dropped. In both alternatives the estimated $\psi$ statistics were higher than at the previous table, at odds to the expected bias described by Bikker et al. (2006); furthermore, the resulting decrease in explanatory power, in some cases, led us to not reject the perfect competition hypothesis.

The test was also carried out assuming deposits are not inputs to the banking firm, and the results - which also point out to a rejection of both hypotheses of perfect competition and monopoly - are presented on the bottom panel of Table 3.

Since the results do not seem to be driven by the behavior of any subgroup in our sample neither by scale effects bias such as pointed out by Bikker et al. (2006), the next step was to investigate of the markets can be considered in Long-Run equilibrium. The usual test for this hypothesis, as discussed before, involves the sum of elasticities of factor prices with respect to companies' profits. This test will be carried out by using the following specification

$$
\begin{aligned}
& \ln \left(R T_{i t}-C_{i t}\right)=\beta_{1} \ln \left(A G N_{i t}\right)+\beta_{2} \ln \left(C R D_{i t}\right)+\beta_{3} \ln \left(D E P S_{i t}\right)+ \\
& +\beta_{4} \ln \left(W 1_{i t}\right)+\beta_{5} \ln \left(R D E P S_{i t}\right)+\beta_{6} \ln \left(W 3_{i t}\right)+f_{i}+\varepsilon_{i t}
\end{aligned}
$$

This profit tests for the complete sample and the subsamples discussed previously are on the following table. Alternative specifications without the $\ln \left(D E P S_{i t}\right)$ and $\ln \left(A G N_{i t}\right)$ were also tried in order to compare the results to the versions of the Panzar-Rosse test, and also alternatives which do not assume deposits to be inputs to the banking firm (on the bottom panel of Table 4): 
Table 4 - Profit Test - Deposits as an Input (Top)

\begin{tabular}{|c|c|c|c|c|c|c|}
\hline & $\begin{array}{c}\text { Full } \\
\text { Sample }\end{array}$ & $\begin{array}{l}\text { Large } \\
\text { Banks }\end{array}$ & $\begin{array}{l}\text { Medium } \\
\text { Banks }\end{array}$ & $\begin{array}{r}\text { Small } \\
\text { Banks }\end{array}$ & $\begin{array}{c}\text { Commercial } \\
\text { Banks }\end{array}$ & $\begin{array}{l}\text { Investment } \\
\text { Banks }\end{array}$ \\
\hline $\ln \left(A G N_{i t}\right)$ & $\begin{array}{l}0.411 \text { * } \\
(2.454)\end{array}$ & $\begin{array}{c}0.187 \\
(0.464)\end{array}$ & $\begin{array}{l}0.475 \text { ** } \\
(2.699)\end{array}$ & $\begin{array}{c}0.439 \\
(0.846)\end{array}$ & $\begin{array}{l}0.448 * \\
(2.175)\end{array}$ & $\begin{array}{c}0.223 \\
(0.835)\end{array}$ \\
\hline $\ln \left(C R D_{i t}\right)$ & $\begin{array}{c}0.056 \\
(1.303)\end{array}$ & $\begin{array}{l}-0.029 \\
(-0.197)\end{array}$ & $\begin{array}{c}0.054 \\
(0.922)\end{array}$ & $\begin{array}{c}0.022 \\
(0.334)\end{array}$ & $\begin{array}{c}0.009 \\
(0.088)\end{array}$ & $\begin{array}{c}0.068 \\
(1.872)\end{array}$ \\
\hline $\ln \left(W 1_{i t}\right)$ & $\begin{array}{c}0.074 \\
(1.158)\end{array}$ & $\begin{array}{c}-0.014 \\
(-0.554)\end{array}$ & $\begin{array}{c}0.110 \\
(1.128)\end{array}$ & $\begin{array}{c}0.270 \\
(1.296)\end{array}$ & $\begin{array}{c}0.045 \\
(0.716)\end{array}$ & $\begin{array}{c}0.151 \\
(0.964)\end{array}$ \\
\hline $\ln \left(R D \mathrm{EP}_{i t}\right)$ & $\begin{array}{l}0.487^{\star * \star} \\
(10.064)\end{array}$ & $\begin{array}{l}0.490 \text { ** } \\
(2.733)\end{array}$ & $\begin{array}{l}0.5022^{* * \star} \\
(8.623)\end{array}$ & $\begin{array}{l}0.485^{* * \star} \\
(4.811)\end{array}$ & $\begin{array}{l}0.448^{* * *} \\
(5.330)\end{array}$ & $\begin{array}{l}0.5433^{* \star *} \\
(8.318)\end{array}$ \\
\hline $\ln \left(D E P S_{i t}\right)$ & $\begin{array}{l}0.430^{* * *} \\
(5.725)\end{array}$ & $\begin{array}{c}0.674 \\
(1.806)\end{array}$ & $\begin{array}{l}0.506^{* * *} \\
(5.716)\end{array}$ & $\begin{array}{c}0.076 \\
(0.481)\end{array}$ & $\begin{array}{l}0.5000^{* * *} \\
(3.560)\end{array}$ & $\begin{array}{l}0.318^{* \star *} \\
(3.631)\end{array}$ \\
\hline $\ln \left(W 3_{i t}\right)$ & $\begin{array}{l}0.163 \text { ** } \\
(3.169)\end{array}$ & $\begin{array}{l}0.256 \text { * } \\
(2.203)\end{array}$ & $\begin{array}{l}0.1477^{* *} \\
(2.647)\end{array}$ & $\begin{array}{c}0.036 \\
(0.172)\end{array}$ & $\begin{array}{l}0.221^{* * *} \\
(3.523)\end{array}$ & $\begin{array}{c}0.056 \\
(0.414)\end{array}$ \\
\hline Constant & $\begin{array}{l}8.1122^{* * *} \\
(4.405)\end{array}$ & $\begin{array}{c}3.461 \\
(0.445)\end{array}$ & $\begin{array}{l}7.450^{* * *} \\
(3.985)\end{array}$ & $\begin{array}{l}11.136 \text { * } \\
(2.135)\end{array}$ & $\begin{array}{l}7.485 \text { ** } \\
(2.736)\end{array}$ & $\begin{array}{l}7.666^{* *} \\
(2.969)\end{array}$ \\
\hline Number of Obs. & 2458 & 571 & 1396 & 491 & 1332 & 1126 \\
\hline R-sq & 0.202 & 0.170 & 0.237 & 0.206 & 0.179 & 0.228 \\
\hline Test Stat & 0.725 & 0.733 & 0.759 & 0.791 & 0.715 & 0.750 \\
\hline $\mathrm{H}=0$ (p-value) & 0.000 & 0.000 & 0.000 & 0.000 & 0.000 & 0.000 \\
\hline & $\begin{array}{c}\text { Full } \\
\text { Sample }\end{array}$ & $\begin{array}{l}\text { Large } \\
\text { Banks }\end{array}$ & $\begin{array}{l}\text { Medium } \\
\text { Banks }\end{array}$ & $\begin{array}{r}\text { Small } \\
\text { Banks }\end{array}$ & $\begin{array}{c}\text { Commercial } \\
\text { Banks }\end{array}$ & $\begin{array}{l}\text { Investment } \\
\text { Banks }\end{array}$ \\
\hline $\ln \left(A G N_{i t}\right)$ & $\begin{array}{l}0.530 \text { ** } \\
(2.966)\end{array}$ & $\begin{array}{c}0.287 \\
(0.748)\end{array}$ & $\begin{array}{l}0.597 \text { ** } \\
(3.197)\end{array}$ & $\begin{array}{c}0.640 \\
(0.993)\end{array}$ & $\begin{array}{c}0.522 \text { * } \\
(2.486)\end{array}$ & $\begin{array}{c}0.371 \\
(1.071)\end{array}$ \\
\hline $\ln \left(C R D_{i t}\right)$ & $\begin{array}{l}0.086 \text { * } \\
(2.026)\end{array}$ & $\begin{array}{c}0.074 \\
(0.628)\end{array}$ & $\begin{array}{c}0.051 \\
(0.807)\end{array}$ & $\begin{array}{c}0.109 \\
(1.778)\end{array}$ & $\begin{array}{c}0.009 \\
(0.088)\end{array}$ & $\begin{array}{l}0.104 \text { * } \\
(2.509)\end{array}$ \\
\hline $\ln \left(W 1_{i t}\right)$ & $\begin{array}{l}0.231 \text { * } \\
(2.463)\end{array}$ & $\begin{array}{c}0.079 \\
(1.331)\end{array}$ & $\begin{array}{l}0.3599^{* * *} \\
(3.438)\end{array}$ & $\begin{array}{c}0.356 \\
(1.645)\end{array}$ & $\begin{array}{c}0.157 \\
(1.796)\end{array}$ & $\begin{array}{l}0.450 \text { ** } \\
(2.769)\end{array}$ \\
\hline $\ln \left(D E P S_{i t}\right)$ & $\begin{array}{l}0.341^{* * *} \\
(3.906)\end{array}$ & $\begin{array}{c}0.546 \\
(1.388)\end{array}$ & $\begin{array}{l}0.355^{* * *} \\
(3.577)\end{array}$ & $\begin{array}{c}0.106 \\
(0.493)\end{array}$ & $\begin{array}{l}0.324 \text { * } \\
(2.203)\end{array}$ & $\begin{array}{l}0.276 \text { * } \\
(2.630)\end{array}$ \\
\hline $\ln \left(W 3_{i t}\right)$ & $\begin{array}{l}0.217^{* * *} \\
(3.479)\end{array}$ & $\begin{array}{l}0.406^{* * *} \\
(4.219)\end{array}$ & $\begin{array}{l}0.154 \text { * } \\
(2.585)\end{array}$ & $\begin{array}{c}0.139 \\
(0.616)\end{array}$ & $\begin{array}{l}0.288^{* * *} \\
(4.383)\end{array}$ & $\begin{array}{c}0.107 \\
(0.714)\end{array}$ \\
\hline Constant & $\begin{array}{l}8.043^{* * *} \\
(3.860)\end{array}$ & $\begin{array}{c}4.472 \\
(0.537)\end{array}$ & $\begin{array}{l}7.816^{* * *} \\
(3.639)\end{array}$ & $\begin{array}{l}10.482 \\
(1.587)\end{array}$ & $\begin{array}{l}8.789 \text { ** } \\
(2.944)\end{array}$ & $\begin{array}{c}6.301 \\
(1.973)\end{array}$ \\
\hline Number of Obs. & 2458 & 571 & 1396 & 491 & 1332 & 1126 \\
\hline R-sq & 0.132 & 0.130 & 0.165 & 0.120 & 0.135 & 0.123 \\
\hline Test Stat & 0.448 & 0.486 & 0.512 & 0.495 & 0.444 & 0.557 \\
\hline $\mathrm{H}=0$ (p-value) & 0.000 & 0.000 & 0.000 & 0.000 & 0.000 & 0.000 \\
\hline
\end{tabular}

Obs: Asymptotic t Stats in Parentheses. Codes: P-value $<0.01{ }^{* * *}, \mathrm{P}$-value $<0.05^{* *}$ and value $<0.1$.

The previous result point to a rejection of the hypothesis at one percent significance level the observed data is consistent with long-run equilibrium behavior, indicating 
the rather restrictive assumptions required for the usage of Panzar-Rosse statistic as a competition test are soundly rejected. For the balanced sample, the results were qualitatively similar, pointing out to the rejection of the underlying assumptions of the Panzar-Rosse test. This conclusion also obtained when the scale variables are removed from the test equation for a comparison with the test in accordance to the conclusions of Bikker et al. (2006).

The importance of this fact must not be underestimated, since all previous tests using the Panzar-Rosse methodology did not present the results of the long run equilibrium test, putting in check the conslusions raised by both Araújo et al. (2005) and Belaisch (2003) concerning the competitive structure of this industry. As for the constructive conclusions of the tests above, one is only able to reject the hypothesis of a joint profit maximizing oligopoly (that is, cartel behavior) by Brazilian banks. However, for more specific conclusions regarding the characterization of competition, a different approach must be tried, the theme of the next section.

\subsection{The Conjectural Variations Approach}

On this section, an alternative approach is explored to identify the competitive conduct, in which the relevant parameters are understood to reflect the firms' "expectations" about the reaction of their competitors to increased output. More specifically, the version of Gollop and Roberts (1979) presented in the analysis of Spanish banking by Moreno, Martínez and Ruiz (2006) was developed here.

Their model begins by posing an inverse demand function for loans:

$$
R_{t}=D\left(\sum_{i} C R E D S_{i t}\right)
$$

In which $D^{\prime}(\cdot)<0$, and indicates the market opportunity cost of credit $-R_{t}$ at the time period $t$ - is a decreasing function of the aggregate volume of loans, the sum of $C R E D S_{i t}{ }^{14}$ at time period $t$ over all banks denoted $i$. The lending rate for an individual bank could be expressed as the sum of the opportunity cost of funds, $R_{t}$, and a bank specific variable which collects the differences in service quality. In a sense, the $v_{i t}$ variable could be understood as capturing the product differentiation aspects of the banking services. Thus, the loan rate charged by each bank could be written as:

$$
\begin{aligned}
& R C R E D_{i t}=R_{t}+v_{i t} \\
& R C R E D_{i t}=D\left(\sum_{i} C R E D S_{i t}\right)+v_{i t}
\end{aligned}
$$

14 The $i$ subscripts refer to individual banks. 
The cost function, on the other hand, could be separated on the following way:

$$
C_{i t}=Z_{i t} \times C R E D S_{i t}+c\left(C R E D S_{i t}, D E P S_{i t}, W 1_{i t}, W 3_{i t}\right)
$$

On the previous equation, $Z_{i t}$ is defined as the interbank rate under which additional funds could also be borrowed in order to increase lending. The $c(\cdot)$ function represent the operating costs, depending on factor prices (labor and capital), as well as on scale of loans and deposits. From the definition of economic profit, substitution of the cost function defined previously leads to:

$$
\Pi_{i}=\left(R C R E D_{i t}-Z_{i t}\right) \times C R E D S_{i t}-c\left(D E P S_{i t}, W 1_{i t}, W 3_{i t}\right)
$$

Assuming the strategic variable for banks is the volume of loans, differentiation of the profit function with respect to $\mathrm{C} R \mathrm{E} D \mathrm{~S}_{i t}$ leads to, after reorganization:

$$
\frac{R C R E D_{i t}-Z_{i t}-C M g_{i t}}{R C R E D_{i t}}=\frac{S_{i t}}{\varepsilon D}\left(1+\sum_{k \neq i} \frac{\partial C R E D S_{k t}}{\partial C R E D S_{i t}}\right)\left(\frac{1-v_{i t}}{R C R E D_{i t}}\right)
$$

In which $S_{i t}$ is the market share of bank $i$ on time period $t, \varepsilon D$ is the price elasticity of demand with respect to credit rate $-\frac{\partial R_{t}}{\partial\left(\sum_{i} C R E D S_{i t}\right)} \times \frac{\sum_{i} C R E D S_{i t}}{R_{t}}$. The term $\sum_{k \neq i} \frac{\partial C R E D S_{k t}}{\partial C R E D S_{i t}}{ }^{15}$ is also known as the conjectural variation expected by bank $i$ (that is, the sum of expected changes on the quantity supplied by the firms' competitors in response to a change on its own quantity). ${ }^{16}$ Usually not enough degrees of freedom for estimating each conjectural variation were available, and it is proposed here a technique to reduce the number of coefficients to be estimated. ${ }^{17}$ It is important to emphasize, though, that despite the different name, this conjectural variation is the same thing as the conduct parameter discussed above.

The technique proposed involves rewriting the summation above in terms of ${ }^{\mathrm{s}} \mathrm{di}$ fferent groups, defined by their size (less than 250 million BRL in assets, between

15 An important result in the analysis is $\sum_{k \neq i} \frac{\partial C R E D S_{k t}}{\partial C R E D S_{i t}}=\frac{\partial \sum_{k \neq i} C R E D S_{k t}}{\partial C R E D S_{i t}}$

16 Recent criticisms of the concept of conduct parameter include Corts (1998), which indicate any structural change in demand and supply variables would make the identification assumptions suspect. Furthermore, Wolfram (1999), Corts (1998) and Puller (2007) conclude the test might only be used to discriminate between competition, collusion and Cournot Equilibrium. Even so, this diminished interpretation of the conduct parameter is an improvement over the results of the previous section.

17 Nevo (1998) makes a related point regarding the identification of conduct parameters in such situations, for which he advocates using tests of non-nested hypotheses. 
250 and 5,000 million and above 5,000 million in assets) leading to the following equation:

$$
\frac{R C R E D_{i t}-Z_{i t}-C M g_{i t}}{R C R E D_{i t}}=\frac{S_{i t}}{\varepsilon_{D}}\left(1+\sum_{h=1}^{s} \frac{\partial\left(\sum_{k \in h, k \neq i} C R E D S_{k t}\right)}{\partial C R E D S_{i t}}\right)\left(1-\frac{v_{i t}}{R C R E D_{i t}}\right)
$$

This equation expressing the conjectural variation can be rewritten in relative terms:

$$
\frac{R C R E D_{i t}-Z_{i t}-C M g_{i t}}{R C R E D_{i t}}=\frac{S_{i t}}{\varepsilon_{D}}\left(1+\sum_{h=1}^{s}\left[\left(\sum_{k \in h, k \neq i} C R E D S_{k t}\right) \frac{\partial \ln \left(\sum_{k \in h, k \neq i} C R E D S_{k t}\right)}{\partial C R E D S_{i t}}\right]\right)\left(1-\frac{v_{i t}}{R C R E D_{i t}}\right)
$$

The term $\frac{\partial \ln \left(\sum_{k \in h, k \neq i} C R E D S_{k t}\right)}{\partial C R E D S_{i t}}$ would be the relative conjectural variation, the expected percentage response to an one million BRL in credit supply by bank $i$. However, the imposition of a same conjecture for every firm in each category implies that banks closer to each other, but belonging to different groups might possess very different conjectures (GOLLOP; ROBERTS, 1979, p. 316). The solution presented by Gollop and Roberts (1979) and adopted by Moreno, Martínez and Ruiz (2006) was to select some firms as benchmarks. The conjectural variation of each firm with respect to each group will be a weighted average of the conjectural variations for each of the benchmarks.

Thus, the term $\frac{\partial \ln \left(\sum_{k \in h, k \neq i} C R E D S_{k t}\right)}{\partial C R E D S_{i t}}$ is a parameter to be estimated, $\beta_{h}^{j}$, in which $j$ is an array composed of two elements - Top or Bottom and the group number. The $h$ is the group to which the reaction refers, so the term $\beta_{1}^{T 1}$ means the response of the largest firm on the first group to changes in the CREDS variable of the companies in the first group.

For a firm $i$ located between the benchmarks $j-1$ and $j$, the $\beta_{h}^{i}=w_{i} \beta_{h}^{L i}+\left(1-w_{i}\right) \beta_{h}^{T i}$, in which $\beta_{h}^{L i}$ and $\beta_{h}^{T i}$ are the conjectures of the smallest and largest firms in which bank $i$ is classified. The $W_{i}$, on the other hand, is a measure of the distance between $i$ firm and the smallest firm in the group. Thus, the previous equation can be rewritten as:

$$
\frac{R C R E D_{i t}-Z_{i t}-C M g_{i t}}{R C R E D_{i t}}=\frac{S_{i t}}{\varepsilon_{D}}\left(1+\sum_{h=1}^{s}\left[\left(\sum_{k \in h, k \neq i} C R E D S_{k t}\right)\left(w_{k} \beta_{h}^{L k}+\left(1-w_{k}\right) \beta_{h}^{T k}\right)\right]\right)\left(1-\frac{v_{i t}}{R C R E D_{i t}}\right)
$$


In order to estimate this model, two other points must be addressed. The first one relates to the fact the market shares - the $S_{i t}$ variable - and margins are simultaneously determined. This problem was faced by specifying a reduced form equation for the market share of bank $i$, presented below:

$$
S_{i t}=\psi_{0}+\psi_{1} \text { CR } 3 S H A R E_{i t}+\psi_{2} Y_{i t}+\psi_{3} \operatorname{ASSEMP}_{i t}
$$

The other problem is the marginal cost usually is not directly observed (studies such as of Wolfram (1999)which had quite reliable independent estimates of marginal costs are quite rare). Even considering accounting data, one of the most important characteristics of the New Empirical Industrial Organization models is that marginal cost is not an observable quantity. The cost side of the firms was modeled using a translog specification combined with the input relations derived from Shepard's Lemma. Considering a view of the banking firm in which it provides two services - deposits and credits - and demanding two factors, labor and physical capital, the following system of equations is the cost side of the model:

$$
\begin{aligned}
& \ln C_{i t}=\alpha_{0}+\alpha_{1} \ln C R E D S_{i t}+\alpha_{2} \ln D E P S_{i t}+\alpha_{3} \ln C R E D S_{i t} \times \ln D E P S_{i t}+ \\
& +0.5 \alpha_{4}\left(\ln C R E D S_{i t}\right)^{2}+0.5 \alpha_{5}\left(\ln D E P S_{i t}\right)^{2}+\gamma_{1} \ln \left(W 1_{i t}\right)+\gamma_{2} \ln \left(W 3_{i t}\right)+ \\
& +\gamma_{3} \ln \left(W 1_{i t}\right) \times \ln \left(W 3_{i t}\right)+0.5 \gamma_{4}(\ln (W 1))^{2}+0.5 \gamma_{5}\left(\ln \left(W 3_{i t}\right)\right)^{2}+ \\
& +\delta_{1} \ln \left(C R E D S_{i t}\right) \times \ln \left(W 1_{i t}\right)+\delta_{2} \ln \left(C R E D S_{i t}\right) \times \ln \left(W 3_{i t}\right)+\delta_{3} \ln \left(D E P S_{i t}\right) \times \ln \left(W 1_{i t}\right)+ \\
& +\delta_{4} \ln \left(D E P S_{i t}\right) \times \ln \left(W 3_{i t}\right) \\
& S U 1_{i t}=\gamma_{1}+\gamma_{4} \ln \left(W 1_{i t}\right)+\gamma_{3} \ln \left(W 3_{i t}\right)+\delta_{1} \ln \left(C R E D S_{i t}\right)+\delta_{3} \ln \left(D E P S_{i t}\right) \\
& S U 3_{i t}=\gamma_{2}+\gamma_{5} \ln \left(W 3_{i t}\right)+\gamma_{3} \ln \left(W 1_{i t}\right)+\delta_{2} \ln \left(C R E D S_{i t}\right)+\delta_{4} \ln \left(D E P S_{i t}\right)
\end{aligned}
$$

The system of equations (3)-(5), which the SU1 and SU2 variables are the shares of labor and physical capital in total costs, imply the marginal cost of credits as being:

$$
C M g_{i t}=\frac{C_{i t}}{C R E D S_{i t}}\left(\alpha_{1}+\alpha_{3} \ln D E P S_{i t}+\alpha_{4} \ln \left(C R E D S_{i t}\right)+\delta_{1} \ln \left(W 1_{i t}\right)+\delta_{2} \ln \left(W 3_{i t}\right)\right)
$$

The empirical analysis was carried out in two steps; on the first one the system of equations 3-5 was estimated, and with the coefficients the predicted marginal costs were computed using equation (6). With the predicted marginal costs, the system $1-2$ was estimated. ${ }^{18}$ The estimation method used was the Seemingly Unrelated Regressions system, and the results are on the following tables:

18 The equation (1) was estimated by expanding the parentheses and the $v_{i t}$ variable was approximated by the ratio of workers per branch, the $Q U A L_{i t}$ variable. 
Table 5 - System of Equations (3)-(5)

\begin{tabular}{|c|c|c|c|c|c|c|}
\hline & Restr. & No Restr. & & Restr. & & No Restr. \\
\hline \multicolumn{7}{|l|}{ Eqn. 3} \\
\hline $\ln \left(D E P S_{i t}\right)$ & $\begin{array}{c}0.065 \\
(0.222)\end{array}$ & $\begin{array}{c}1.322 \\
(4.043)\end{array}$ & $\star * *$ & $\begin{array}{c}1.794 \\
(3.573)\end{array}$ & $* \star *$ & $\begin{array}{l}2.204^{\text {***}} \\
(4.232)\end{array}$ \\
\hline $\ln \left(C R E D S_{i t}\right)$ & $\begin{array}{l}0.744 \text { * } \\
(2.091)\end{array}$ & $\begin{array}{c}-0.733 \\
(-1.868)\end{array}$ & & $\begin{array}{l}-2.641 \\
(-4.298)\end{array}$ & *** & $\begin{array}{l}-3.177^{* * *} \\
(-5.013)\end{array}$ \\
\hline$\left(\ln \left(D E P S_{i t}\right)\right) 2$ & $\begin{array}{l}0.368^{* * *} \\
(7.553)\end{array}$ & $\begin{array}{c}0.327 \\
(6.183)\end{array}$ & $\star * \star$ & $\begin{array}{c}0.345 \\
(5.598)\end{array}$ & *** & $\begin{array}{l}0.248^{\text {*** }} \\
(3.819)\end{array}$ \\
\hline$\left(\ln \left(C R E D S_{i t}\right)\right) 2$ & $\begin{array}{l}0.170 \text { * } \\
(1.993)\end{array}$ & $\begin{array}{c}0.203 \\
(2.267)\end{array}$ & * & $\begin{array}{c}0.555 \\
(4.328)\end{array}$ & $* * *$ & $\begin{array}{l}0.423 \text { ** } \\
(3.157)\end{array}$ \\
\hline $\ln \left(D E P S_{i t}\right) \times \ln \left(C R E D S_{i t}\right)$ & $\begin{array}{l}-0.263^{* * *} \\
(-4.137)\end{array}$ & $\begin{array}{c}-0.245 \\
(-3.618)\end{array}$ & $* * *$ & $\begin{array}{c}-0.390 \\
(-4.373)\end{array}$ & *** & $\begin{array}{l}-0.265^{\text {** }} \\
(-2.817)\end{array}$ \\
\hline $\ln \left(W 1_{i t}\right)$ & $\begin{array}{l}0.538 \text { *** } \\
(25.647)\end{array}$ & $\begin{array}{c}1.014 \\
(14.137)\end{array}$ & $\star \star \star *$ & $\begin{array}{c}0.557 \\
(16.118)\end{array}$ & $* * *$ & $\begin{array}{l}0.831^{* * *} \\
(8.305)\end{array}$ \\
\hline $\ln \left(W 3_{i t}\right)$ & $\begin{array}{l}0.4622^{* * *} \\
(22.064)\end{array}$ & $\begin{array}{c}-0.014 \\
(-0.189)\end{array}$ & & $\begin{array}{c}0.443 \\
(12.795)\end{array}$ & *** & $\begin{array}{c}0.169 \\
(1.688)\end{array}$ \\
\hline$\left(\ln \left(W 1_{i t}\right)\right) 2$ & $\begin{array}{l}-0.0766^{* * *} \\
(-53.429)\end{array}$ & $\begin{array}{c}-0.035 \\
(-12.357)\end{array}$ & *** & $\begin{array}{c}-0.014 \\
(-11.973)\end{array}$ & *** & $\begin{array}{l}-0.002 \\
(-0.874)\end{array}$ \\
\hline$\left(\ln \left(W 3_{i t}\right)\right) 2$ & $\begin{array}{c}0.119^{* * *} \\
(107.589)\end{array}$ & $\begin{array}{c}0.119 \\
(36.504)\end{array}$ & $\star \star \star *$ & $\begin{array}{r}0.030 \\
(23.976)\end{array}$ & *** & $\begin{array}{l}0.033^{\text {*** }} \\
(9.186)\end{array}$ \\
\hline $\ln \left(W 1_{i t}\right) \times \ln \left(W 3_{i t}\right)$ & $\begin{array}{c}-0.044 \\
(-28.465)\end{array}$ & $\begin{array}{c}-0.084 \\
(-29.227)\end{array}$ & 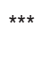 & $\begin{array}{c}-0.016 \\
(-15.171)\end{array}$ & *** & $\begin{array}{l}-0.0311^{* * *} \\
(-9.416)\end{array}$ \\
\hline $\ln \left(W 1_{i t}\right) \times \ln \left(D E P S_{i t}\right)$ & $\begin{array}{l}-0.131 \\
(-15.380)\end{array}$ & $\begin{array}{c}-0.421 \\
(-15.376)\end{array}$ & $* * *$ & $\begin{array}{c}-0.113 \\
(-14.260)\end{array}$ & *** & $\begin{array}{l}-0.343^{* * *} \\
(-12.302)\end{array}$ \\
\hline $\ln \left(W 1_{i t}\right) \times \ln \left(C R E D S_{i t}\right)$ & $\begin{array}{l}0.125^{* * *} \\
(13.837)\end{array}$ & $\begin{array}{r}0.372 \\
(12.746)\end{array}$ & $\star \star \star *$ & $\begin{array}{c}0.104 \\
(12.071)\end{array}$ & *** & $\begin{array}{l}0.310^{* * *} \\
(10.301)\end{array}$ \\
\hline $\ln \left(W 3_{i t}\right) \times \ln \left(D E P S_{i t}\right)$ & $\begin{array}{l}-0.071^{\text {*** }} \\
(-9.932)\end{array}$ & $\begin{array}{c}-0.099 \\
(-7.288)\end{array}$ & *** & $\begin{array}{c}-0.097 \\
(-11.309)\end{array}$ & *** & $\begin{array}{l}-0.060 \text { ** } \\
(-2.713)\end{array}$ \\
\hline $\ln \left(W 3_{i t}\right) \times \ln \left(C R E D S_{i t}\right)$ & $\begin{array}{l}0.077^{* * *} \\
(10.010)\end{array}$ & $\begin{array}{c}0.148 \\
(9.225)\end{array}$ & $\star \star \star *$ & $\begin{array}{c}0.106 \\
(11.557)\end{array}$ & *** & $\begin{array}{l}0.093^{* * *} \\
(3.746)\end{array}$ \\
\hline Constant & $\begin{array}{l}-2.190 \text { ** } \\
(-3.258)\end{array}$ & $\begin{array}{l}-1.746 \\
(-2.429)\end{array}$ & * & $\begin{array}{l}10.226 \\
(5.345)\end{array}$ & *** & $\begin{array}{l}10.858^{\text {*** }} \\
(5.350)\end{array}$ \\
\hline Eqn. 4 & & & & & & \\
\hline $\ln \left(W 1_{i t}\right)$ & $\begin{array}{l}-0.0766^{* * *} \\
(-53.429)\end{array}$ & $\begin{array}{c}-0.007 \\
(-4.840)\end{array}$ & $\star * *$ & $\begin{array}{c}-0.014 \\
(-11.973)\end{array}$ & $* * *$ & $\begin{array}{c}-0.002 \\
(-1.327)\end{array}$ \\
\hline $\ln \left(W 3_{i t}\right)$ & $\begin{array}{l}-0.044 \\
(-28.465)\end{array}$ & $\begin{array}{c}0.004 \\
(2.823)\end{array}$ & ** & $\begin{array}{c}-0.016 \\
(-15.171)\end{array}$ & *** & $\begin{array}{l}-0.010 \text { *** } \\
(-7.732)\end{array}$ \\
\hline $\ln \left(D E P S_{i t}\right)$ & $\begin{array}{l}-0.131 \\
(-15.380)\end{array}$ & $\begin{array}{l}-0.041 \\
(-9.144)\end{array}$ & $\star * *$ & $\begin{array}{r}-0.113 \\
(-14.260)\end{array}$ & *** & $\begin{array}{l}-0.057 \\
(-10.267)\end{array}$ \\
\hline $\ln \left(C R E D S_{i t}\right)$ & $\begin{array}{l}0.125^{* * *} \\
(13.837)\end{array}$ & $\begin{array}{c}0.034 \\
(6.888)\end{array}$ & $\star * \star$ & $\begin{array}{c}0.104 \\
(12.071)\end{array}$ & *** & $\begin{array}{l}0.019 \\
(2.875)\end{array}$ \\
\hline Constant & $\begin{array}{l}0.538^{* * *} \\
(25.647)\end{array}$ & $\begin{array}{r}0.254 \\
(15.828)\end{array}$ & $\star \star * *$ & $\begin{array}{c}0.557 \\
(16.118)\end{array}$ & *** & $\begin{array}{l}0.620^{* * *} \\
(14.455)\end{array}$ \\
\hline Eqn. 5 & & & & & & \\
\hline $\ln \left(W 1_{i t}\right)$ & $\begin{array}{l}-0.044^{* * *} \\
(-28.465)\end{array}$ & $\begin{array}{l}-0.006 \\
(-3.531)\end{array}$ & *** & $\begin{array}{c}-0.016 \\
(-15.171)\end{array}$ & $* * *$ & $\begin{array}{l}-0.0099^{* * *} \\
(-5.707)\end{array}$ \\
\hline $\ln \left(W 3_{i t}\right)$ & $\begin{array}{c}0.119 \\
(107.589)\end{array}$ & $\begin{array}{r}0.036 \\
(21.319)\end{array}$ & $* \star *$ & $\begin{array}{r}0.030 \\
(23.976)\end{array}$ & *** & $\begin{array}{l}0.015^{* * *} \\
(7.859)\end{array}$ \\
\hline $\ln \left(D E P S_{i t}\right)$ & $\begin{array}{l}-0.071^{* * *} \\
(-9.932)\end{array}$ & $\begin{array}{c}0.023 \\
(4.612)\end{array}$ & $\star \star *$ & $\begin{array}{c}-0.097 \\
(-11.309)\end{array}$ & *** & $\begin{array}{l}-0.056^{\text {*** }} \\
(-7.217)\end{array}$ \\
\hline $\ln \left(C R E D S_{i t}\right)$ & $\begin{array}{l}0.077^{* * *} \\
(10.010)\end{array}$ & $\begin{array}{l}-0.048 \\
(-8.694)\end{array}$ & $\star * *$ & $\begin{array}{c}0.106 \\
(11.557)\end{array}$ & *** & $\begin{array}{l}0.035^{* * *} \\
(3.723)\end{array}$ \\
\hline Constant & $\begin{array}{l}0.462^{* * *} \\
(22.064)\end{array}$ & $\begin{array}{r}0.593 \\
(32.888)\end{array}$ & $\star \star * *$ & $\begin{array}{r}0.443 \\
(12.795)\end{array}$ & *** & $\begin{array}{l}0.424^{* * *} \\
(7.085)\end{array}$ \\
\hline $\begin{array}{l}\text { Bank Fixed Effects } \\
\text { Number of Obs. }\end{array}$ & $\begin{array}{l}\text { No } \\
2458\end{array}$ & $\begin{array}{l}\text { No } \\
2458\end{array}$ & & $\begin{array}{l}\text { Yes } \\
2458\end{array}$ & & $\begin{array}{l}\text { Yes } \\
2458\end{array}$ \\
\hline R-sq 1st eqn. & 0.863 & 0.885 & & 0.942 & & 0.946 \\
\hline R-sq 2nd eqn. & -1.904 & 0.078 & & 0.697 & & 0.819 \\
\hline R-sq 3rd eqn. & -0.759 & 0.336 & & 0.706 & & 0.800 \\
\hline
\end{tabular}

Obs: Asymptotic $\mathrm{t}$ Stats in Parentheses. Codes: P-value $<0.01^{* * *}, \mathrm{P}$-value $<0.05^{* *}$ and P-value $<0.1$. 
The cost side equation was estimated in four different ways, depending if the crossequation restrictions were imposed ${ }^{19}$ and whether firm specific effects were tried, leading to the four versions presented in the previous page. As a further check on the economic plausibility of the results, the implied markups over marginal costs were computed and the distribution is as follows: ${ }^{20}$
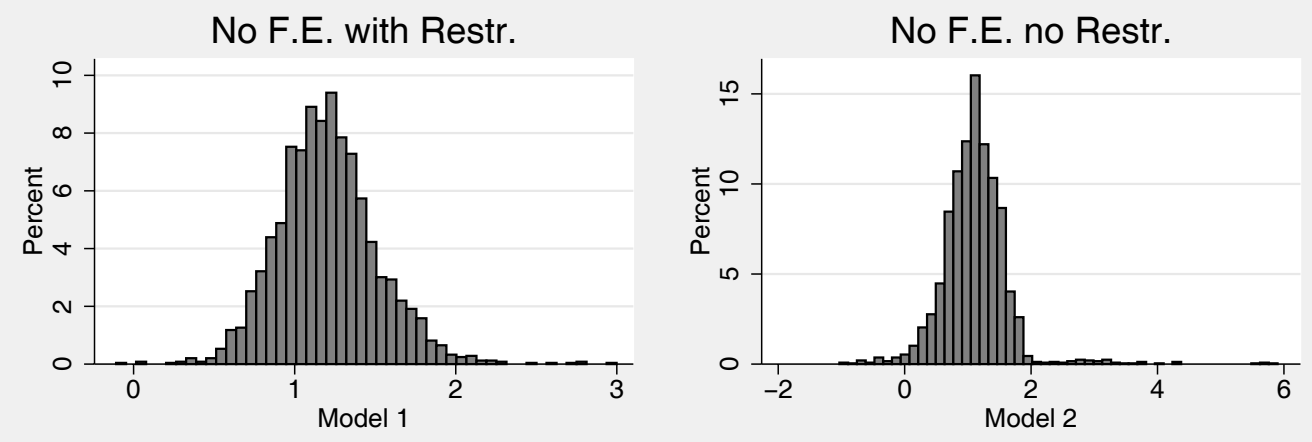

F.E., with Restr.

F.E., no Restr.
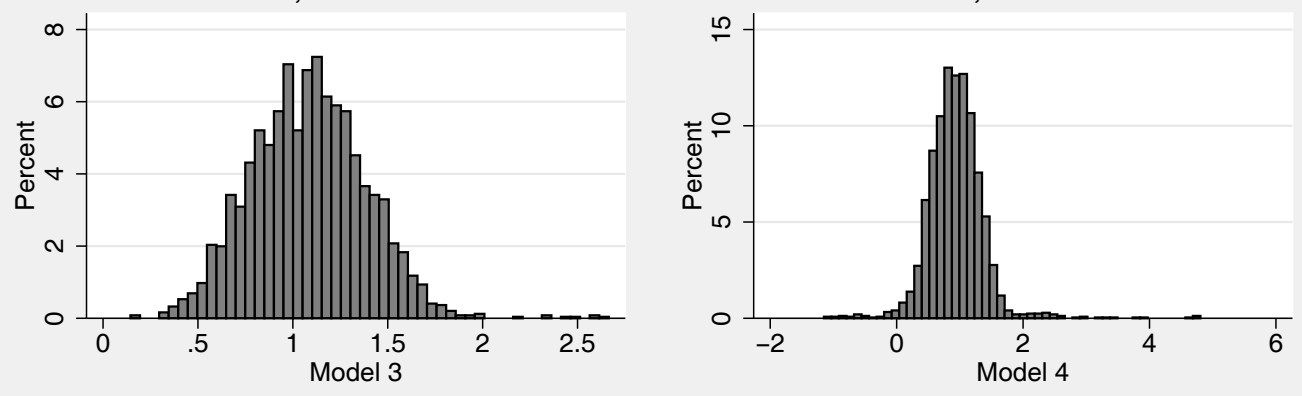

Figure 1 - Distribution of Markups

19 The homogeneity and symmetry restrictions, $\delta=0, \gamma_{3}+\gamma_{4}+\gamma_{5}=0$ and $\gamma_{1}+\gamma_{2}=1$, were imposed in all alternatives.

20 An important point is related to the estimation of the price elasticity of demand. The approach pursued here was based on Shaffer (1993) and starts by posing the following demand function for banking services - understood as banking assets:

$$
\begin{aligned}
& Q_{i t}=a_{0}+a_{1} P_{i t}+a_{2} Y_{i t}+a_{3} Q U A L_{i t}+a_{4} Z_{i t}+a_{5} P_{i t} \times Y_{i t}+ \\
& +a_{6} P_{i t} \times Z_{i t}+a_{7} P_{i t} \times Q U A L_{i t}+a_{8} Y_{i t} \times Z_{i t}+a_{9} Y_{i t} \times Q U A L_{i t}+ \\
& +a_{10} Z_{i t} \times Q U A L_{i t}+\varepsilon_{d i t}
\end{aligned}
$$

In this demand function, $Z_{i t}$ is considered a measure of price of substitutes - since we are considering the sole output of the banking firm as their assets, this should be analugous to the opportunity cost of internally generated funds for the firm which demands credits. On the other hand both $Y_{i t}$ (proxy for income) and $Q U A L_{i t}$ (proxy for quality of services) are demand shifters. The model implied is estimated by Three-Stages Least squares, with a pricing equation. 
The estimated markups obtained after imposing the symmetry and homogeneity tended to present similar averages to the estimates without such restrictions, and lower variance of markups. ${ }^{21}$ Given the estimates of the marginal costs, the pricing side of the model could be estimated. Due to problems of multicollinearity, the conduct parameters were estimated in a way only the expected responses of the largest firm on the sample were estimated directly and the other responses were computed as differences:

Table 6 - System of Equations 1-2

\begin{tabular}{|c|c|c|c|c|c|c|c|c|}
\hline & Model 1 & & Model 2 & & Model 3 & & Model 4 & \\
\hline \multicolumn{9}{|l|}{ Eqn. 1} \\
\hline$\beta_{1}^{L 1}-\beta_{1}^{T 1}$ & $\begin{array}{l}-1.835 \\
(-1.717)\end{array}$ & & $\begin{array}{l}-1.817 \\
(-1.695)\end{array}$ & & $\begin{array}{l}-1.909 \\
(-1.782)\end{array}$ & & $\begin{array}{l}-1.862 \\
(-1.729)\end{array}$ & \\
\hline$\beta_{1}^{T 1}$ & $\begin{array}{l}1.926 \\
(2.853)\end{array}$ & ** & $\begin{array}{l}1.910 \\
(2.821)\end{array}$ & ** & $\begin{array}{l}1.969 \\
(2.912)\end{array}$ & ** & $\begin{array}{l}1.939 \\
(2.850)\end{array}$ & ** \\
\hline$\beta_{1}^{T 1}+\beta_{1}^{T 2}$ & $\begin{array}{l}-1.899 \\
(-2.813)\end{array}$ & ** & $\begin{array}{l}-1.883 \\
(-2.781)\end{array}$ & ** & $\begin{array}{l}-1.942 \\
(-2.871)\end{array}$ & ** & $\begin{array}{l}-1.911 \\
(-2.810)\end{array}$ & ** \\
\hline$\beta_{1}^{T 1}+\beta_{1}^{T 3}$ & $\begin{array}{l}-1.926 \\
(-2.854)\end{array}$ & ** & $\begin{array}{l}-1.911 \\
(-2.822)\end{array}$ & ** & $\begin{array}{l}-1.970 \\
(-2.912)\end{array}$ & ** & $\begin{array}{l}-1.939 \\
(-2.851)\end{array}$ & ** \\
\hline$\beta_{2}^{L 1}-\beta_{2}^{T 1}$ & $\begin{array}{l}0.030 \\
(1.609)\end{array}$ & & $\begin{array}{l}0.030 \\
(1.594)\end{array}$ & & $\begin{array}{l}0.030 \\
(1.593)\end{array}$ & & $\begin{array}{l}0.030 \\
(1.572)\end{array}$ & \\
\hline$\beta_{2}^{T 1}$ & $\begin{array}{l}-0.028 \\
(-2.522)\end{array}$ & * & $\begin{array}{l}-0.028 \\
(-2.506)\end{array}$ & * & $\begin{array}{l}-0.028 \\
(-2.485)\end{array}$ & * & $\begin{array}{l}-0.028 \\
(-2.466)\end{array}$ & * \\
\hline$\beta_{2}^{T 1}+\beta_{2}^{T 2}$ & $\begin{array}{l}0.028 \\
(2.482)\end{array}$ & * & $\begin{array}{l}0.027 \\
(2.466)\end{array}$ & * & $\begin{array}{l}0.027 \\
(2.446)\end{array}$ & * & $\begin{array}{l}0.027 \\
(2.426)\end{array}$ & * \\
\hline$\beta_{2}^{T 1}+\beta_{2}^{T 3}$ & $\begin{array}{l}0.028 \\
(2.503)\end{array}$ & * & $\begin{array}{l}0.028 \\
(2.488)\end{array}$ & * & $\begin{array}{l}0.027 \\
(2.467)\end{array}$ & * & $\begin{array}{l}0.027 \\
(2.447)\end{array}$ & * \\
\hline$\beta_{3}^{L 1}-\beta_{3}^{T 1}$ & $\begin{array}{l}0.002 \\
(0.487)\end{array}$ & & $\begin{array}{l}0.002 \\
(0.479)\end{array}$ & & $\begin{array}{l}0.002 \\
(0.536)\end{array}$ & & $\begin{array}{l}0.002 \\
(0.511)\end{array}$ & \\
\hline$\beta_{3}^{T 1}$ & $\begin{array}{l}-0.005 \\
(-2.059)\end{array}$ & * & $\begin{array}{l}-0.005 \\
(-2.039)\end{array}$ & * & $\begin{array}{l}-0.005 \\
(-2.104)\end{array}$ & * & $\begin{array}{l}-0.005 \\
(-2.065)\end{array}$ & * \\
\hline$\beta_{3}^{T 1}+\beta_{3}^{T 2}$ & $\begin{array}{l}0.004 \\
(2.015)\end{array}$ & * & $\begin{array}{l}0.004 \\
(1.994)\end{array}$ & * & $\begin{array}{l}0.005 \\
(2.059)\end{array}$ & * & $\begin{array}{l}0.005 \\
(2.020)\end{array}$ & * \\
\hline$\beta_{3}^{T 1}+\beta_{3}^{T 3}$ & $\begin{array}{l}0.005 \\
(2.054)\end{array}$ & * & $\begin{array}{l}0.005 \\
(2.033)\end{array}$ & * & $\begin{array}{l}0.005 \\
(2.099)\end{array}$ & * & $\begin{array}{l}0.005 \\
(2.060)\end{array}$ & * \\
\hline$\beta_{1}^{L 2}-\beta_{1}^{T 2}$ & $\begin{array}{l}-0.051 \\
(-3.765)\end{array}$ & $\star \star \star *$ & $\begin{array}{l}-0.051 \\
(-3.760)\end{array}$ & $\star \star \star *$ & $\begin{array}{l}-0.052 \\
(-3.780)\end{array}$ & 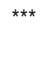 & $\begin{array}{l}-0.052 \\
(-3.774)\end{array}$ & *** \\
\hline$\beta_{2}^{L 2}-\beta_{2}^{T 2}$ & $\begin{array}{l}0.000 \\
(1.383)\end{array}$ & & $\begin{array}{l}0.000 \\
(1.406)\end{array}$ & & $\begin{array}{l}0.000 \\
(1.331)\end{array}$ & & $\begin{array}{l}0.000 \\
(1.357)\end{array}$ & \\
\hline$\beta_{3}^{L 2}-\beta_{3}^{T 2}$ & $\begin{array}{l}0.000 \\
(3.536)\end{array}$ & 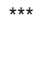 & $\begin{array}{l}0.000 \\
(3.491)\end{array}$ & 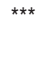 & $\begin{array}{l}0.000 \\
(3.619)\end{array}$ & 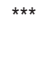 & $\begin{array}{l}0.000 \\
(3.569)\end{array}$ & *** \\
\hline$\beta_{1}^{L 3}-\beta_{1}^{T 3}$ & $\begin{array}{l}0.003 \\
(1.698)\end{array}$ & & $\begin{array}{l}0.003 \\
(1.716)\end{array}$ & & $\begin{array}{l}0.003 \\
(1.760)\end{array}$ & & $\begin{array}{l}0.003 \\
(1.773)\end{array}$ & \\
\hline$\beta_{2}^{L 3}-\beta_{2}^{T 3}$ & $\begin{array}{l}0.000 \\
(0.147)\end{array}$ & & $\begin{array}{l}0.000 \\
(0.167)\end{array}$ & & $\begin{array}{l}0.000 \\
(0.169)\end{array}$ & & $\begin{array}{l}0.000 \\
(0.183)\end{array}$ & \\
\hline$\beta_{3}^{L 3}-\beta_{3}^{T 3}$ & $\begin{array}{l}0.000 \\
(0.766)\end{array}$ & & $\begin{array}{l}0.000 \\
(0.738)\end{array}$ & & $\begin{array}{l}0.000 \\
(0.750)\end{array}$ & & $\begin{array}{l}0.000 \\
(0.725)\end{array}$ & \\
\hline \multicolumn{9}{|l|}{ Eqn. 2} \\
\hline CR3SHARE $E_{i t}$ & $\begin{array}{l}0.046 \\
(2.175)\end{array}$ & * & $\begin{array}{l}0.046 \\
(2.177)\end{array}$ & * & $\begin{array}{l}0.046 \\
(2.169)\end{array}$ & * & $\begin{array}{l}0.046 \\
(2.168)\end{array}$ & * \\
\hline$Y_{i t}$ & $\begin{array}{l}-0.000 \\
(-1.189)\end{array}$ & & $\begin{array}{l}-0.000 \\
(-1.170)\end{array}$ & & $\begin{array}{l}-0.000 \\
(-1.151)\end{array}$ & & $\begin{array}{l}-0.000 \\
(-1.143)\end{array}$ & \\
\hline$A S S E M P_{i t}$ & $\begin{array}{l}-0.000 \\
(-0.480)\end{array}$ & & $\begin{array}{l}-0.000 \\
(-0.448)\end{array}$ & & $\begin{array}{l}-0.000 \\
(-0.489)\end{array}$ & & $\begin{array}{l}-0.000 \\
(-0.459)\end{array}$ & \\
\hline Constant & $\begin{array}{l}0.004 \\
(0.241)\end{array}$ & & $\begin{array}{l}0.003 \\
(0.227)\end{array}$ & & $\begin{array}{l}0.003 \\
(0.213)\end{array}$ & & $\begin{array}{l}0.003 \\
(0.210)\end{array}$ & \\
\hline Number of Obs. & 2458 & & 2458 & & 2458 & & 2458 & \\
\hline R-sq 1st eqn. & 0.395 & & 0.395 & & 0.401 & & 0.400 & \\
\hline R-sq 2nd eqn. & -0.002 & & -0.002 & & -0.002 & & -0.002 & \\
\hline
\end{tabular}

Obs: Asymptotic t Stats in Parentheses. Codes: P-value $<0.01{ }^{* * *}, \mathrm{P}$-value $<0.05^{* *}$ and $\mathrm{P}$-value $<0.1^{*}$.

21 As for the values of the markups, Genesove e Mullin (1998) report that differences in estimated costs tend to have little effect on the estimated conduct parameter, which is the main thrust of this paper. 
For the Model 1, without fixed effects and restrictions, the estimated conduct parameters for a given quarter and their confidence intervals are presented on the following figure: ${ }^{22}$
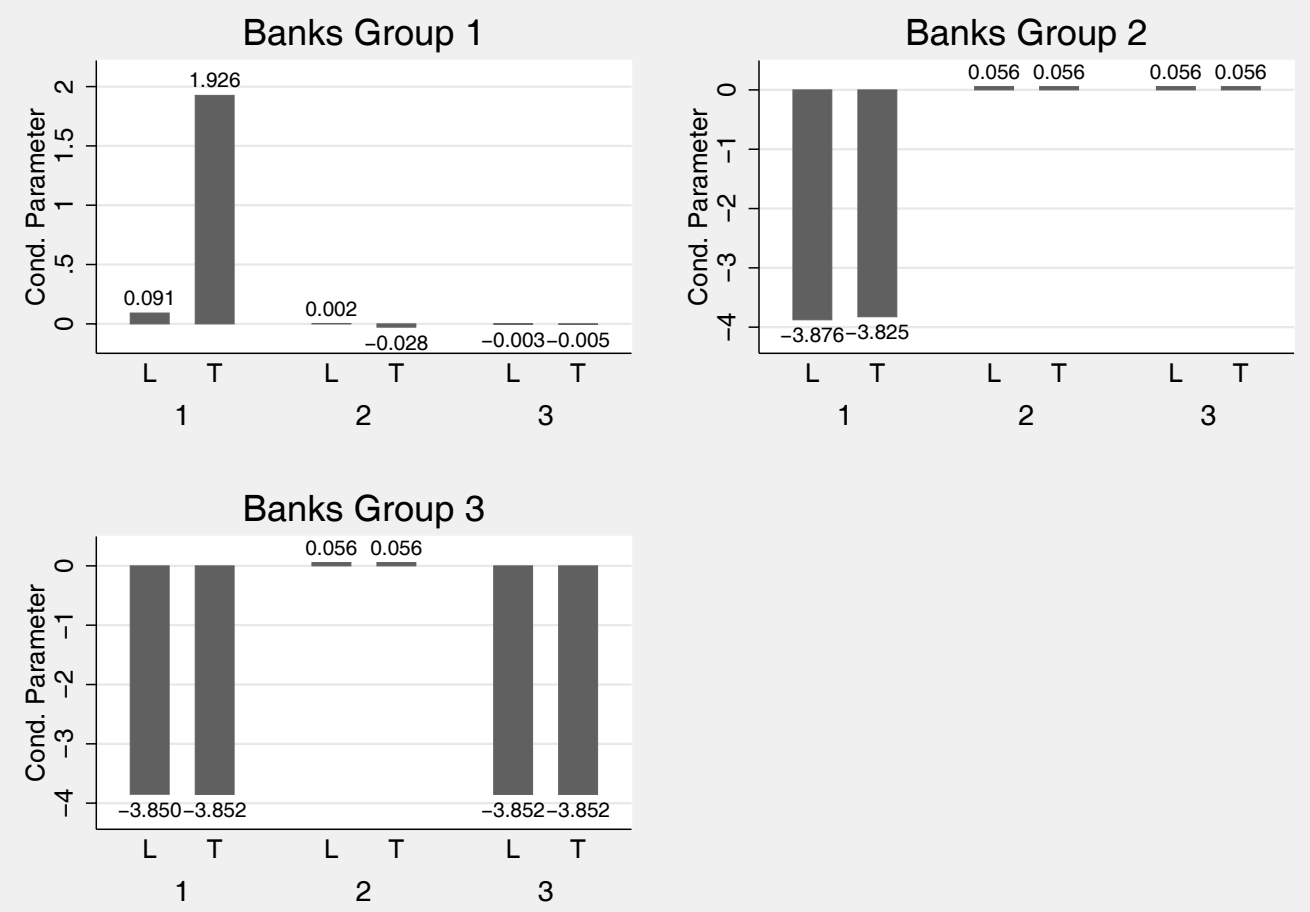

Figure 2 - Estimated Conduct Parameter - 2005/4

Some interesting results in this figure can be inferred. The first one is that there is a great difference between the observed conjectural variations - and by virtue of its definition, also their conduct parameters - for each group. Each of the graphs in the previous table present the response of the reference banks (smallest (L) and largest (T)) with respect to increases in loans by banks in each group.

The resulys in the table point out to firms in group 1 expect an aggressive response by banks in their own group, with their competitors in this group increasing their loan output in response to an increased output, further depressing loan rates. On the other hand, banks in groups 2 and 3 expect a more cooperative response of banks in group 1 to increases in their own output. Banks in group 1 will decrease

22 Results for the other models - quite similar to the ones presented here - are presented on the Appendix A. 
their output in response to increases in loan output by banks in groups 2 and 3, keeping the loan rate to decrease further. And finally, in the largest group of banks, the companies expect a cooperative response of their competitors in the same group, reducing their loans after an increase of output by one of them. This also keeps the loan rate from falling.

The estimated conduct parameters, on the other hand, do not lend themselves to an easy mapping to any of the static oligopoly solutions known on the literature. For instance, the standard Cournot oligopoly result would imply firms to react according to changes in market supply but not according to the source of the change. This implies firms of different sizes have same expectations of relative responses of rivals - according to Gollop and Roberts (1979), p. 322 -, or all $\beta$ to be the same and equal to zero, which inspection of the figure above indicates is not the case.

The adequacy of the standard conduct parameter - the approaches of Bresnahan (1982) and Lau (1982) - can also be tested, by the hypothesis all $\beta$ to be equal, though not necessarily zero, which is also rejected.

Even though the exact competitive assumptions are not revealed by these results, they also point out to another weakness of the Panzar-Rosse (1987) result, which relies on the equality of conduct parameters between firms.

\section{Conclusion}

In this paper, we tried to review existing tests for competition in the Brazilian banking system and propose some alternatives. The first step in the analysis was to describe the institutional changes after the decrease in inflation rates brought about by the Real Plan in 1994. After the description of the institutional setting of the Brazilian Banking system on this period, the competition tests on the literature were reviewed, beginning with the test proposed by Panzar and Rosse (1987). The market did not seem to be in long-run equilibrium, allowing us to conclude nothing else but the market does not seem to find itself in a collusive outcome. This result proved quite robust to different samples, different specifications and definition of inputs of the banking firm.

A new methodology was presented next, based on Gollop and Roberts (1979) and applied by Moreno, Martínez and Ruiz (2006) for the Spanish banking market. On this methodology, in which the assumption of equality of conduct parameters between firms and time periods is relaxed, and is also adopted a different view of 
the input-output structure of the banking firm. The results indicate that, for some firms and in some time periods, a cooperative conduct in fact is present.

All these results point out to a rather limited applicability of the Panzar-Rosse statistic in the Brazilian banking sector, both because of the equilibrium assumptions - which were not verified - as well as the noted heterogeneity of the expected competitive responses by firms in this market. Both results cast doubt in the eventual lack of competition found in the sector.

\section{References}

BELAISCH, Agnes. Do Brazilian banks compete? Washington: International Monetary Fund, 2003. (IMF Working Papers, 03/113).

BIKKER, Jacob A.; HAAF, Katharina. Competition, concentration and their relationship: An empirical analysis of the banking industry. Journal of Banking \& Finance, v. 26, n. 11, p. 2191-2214, 2002.

BIKKER, Jacob; SPIERDIJK, Laura; FINNIE, Paul. Misspecifiation of the PanzarRosse Model: assessing competition in the banking industry. Amsterdam: Netherlands Central Bank, Research Department, 2006. (DNB Working Papers).

BRESNAHAN, Timothy F. The oligopoly solution concept is identified. Economics Letters, v. 10, n. 1-2, p. 87-92, 1982.

CARDOSO, Renato Fragelli; KOYAMA, Sergio Mikio. A cunha fiscal sobre a intermediação financeira. In: Juros e spread bancário no Brasil. BCB/DEPEP, 2000. Appendix.

CETORELLI, Nicola. Competitive analysis in banking: appraisal of the methodologies. Economic Perspectives, I(Q I), p. 2-15, 1999.

CORTS, Kenneth S. Conduct parameters and the measurement of market power. Journal of Econometrics, v. 88, n. 2, p. 227-250, 1998.

COSTA, Ana Carla Abrão. Sistemas Legais de Insolvência, Incentivos e Mercado de Crédito: Uma Abordagem Institucional. In: ENCONTRO NACIONAL DE ECONOMIA, 32, 2004, João Pessoa. Anais.... [Proceedings... ]. João Pessoa: ANPEC - Associação Nacional dos Centros de Pósgraduação em Economia [Brazilian Association of Graduate Programs in Economics], 2004.

COSTA, Ana Carla Abrão; NAKANE, Marcio Issao. Revisitando a metodologia de decomposição do spread bancário no Brasil. In: MEETING OF THE BRAZILIAN ASSOCIATION OF ECONOMETRICS, 26, 2004, João Pessoa. Annals..., João Pessoa: SBE, 2004.

FREIXAS, Xavier; ROCHET, Jean-Charles. Microeconomics of banking. Boulder: Westview, 1997. 
GENESOVE, David; MULLIN, Wallace P. Testing Static Oligopoly Models: conduct and cost in the sugar industry, 1890-1914. RAND Journal of Economics, v. 29, n. 2, p. 355-377, 1998.

GOLLOP, Frank M.; ROBERTS, Mark J. Firm interdependence in oligopolistic markets. Journal of Econometrics, v. 10, n. 3, p. 313-331, 1979.

LOYOLA, Gustavo; OLIVEIRA, Gesner; GUEDES, Ernesto M.; MÜLLER, Bianca. Aspectos concorrenciais no setor bancário brasileiro. Tendências Consultoria Integrada, 2003. (Relatório).

JAUMANDREU, Jordi; LORENCES, Joaquin. Modelling price competition across many markets (An application to the Spanish loans market). European Economic Review, v. 46, n. 1, p. 93-115, 2002.

LAU, Lawrence J. On identifying the degree of competitiveness from industry price and output data. Economics Letters, v. 10, n. 1-2, p. 93-99, 1982.

MORENO, Felipe Ruiz; MARTÍNEZ, Antonio Ladrón de Guevara; RUIZ, Francisco Mas Competencia en el mercado español de créditos bancarios: un modelo de variaciones conjeturales. Valencia: Instituto Valenciano de Investigaciones Económicas, S.A. (Ivie), 2006. (Working Papers. Serie EC, 2006-07).

MATHISEN, Johan; BUCHS, Thierry D. Competition and efficiency in banking: behavioral evidence from Ghana. Washington: International Monetary Fund, 2005. (IMF Working Papers, 05/17.)

NAKANE, Marcio I. Productive efficiency in Brazilian banking sector. São Paulo: IPE/USP, 1999. (Textos para Discussão IPE/USP 20/99).

. A test of competition in Brazilian banking. Brasília: Central Bank of Brazil, Research Department, 2001. (Working Papers Series, 12).

. Concorrência e spread bancário: uma revisão da evidência para o Brasil. Brasília: Banco Central do Brasil, 2003. Available at: < http://www.bcb.gov.br/ Pec/SeminarioEcoBanCre/Port/VI>.

NETO, P. D. M. J.; ARAÚJO, L. A. D.; PONCE, D. A. S. Competição e concentração entre os bancos brasileiros. In: ENCONTRO NACIONAL DE ECONOMIA, 33, 2005, Natal, Brazil. Anais.... [Proceedings...]. Natal: ANPEC - Associação Nacional dos Centros de Pósgraduação em Economia Anais do [Brazilian Association of Graduate Programs in Economics], 2005.

NEVO, A. Identification of the oligopoly solution concept in a differentiated-products industry'. Economics Letters, v. 59, n. 3, p. 391-395, 1998.

PANZAR, J. C.; ROSSE, J. N. Testing for 'Monopoly'; Equilibrium. Journal of Industrial Economics, v. 35, n. 4, p. 443-56, 1987.

PETTERINI, F. C.; JORGE NETO, P. de M. Competição bancária no Brasil após o Plano Real. CAEN/UFC, Fortaleza: CAEN/UFC, 2003. (Textos Para Discussão CAEN/UFC 233). 
PRASAD, A.; GHOSH, S. Competition in Indian Banking. Washington: International Monetary Fund, 2005. (IMF Working Papers 05/141).

PULLER, S. L. Pricing and firm conduct in California's deregulated electricity market. The Review of Economics and Statistics, v. 89, n. 1, p. 75-87, 2007.

SHAFFER, S. Non-structural measures of competition: toward a synthesis of alternatives. Economics Letters, v. 12, n. 3-4, p. 349-353, 1983.

. A test of competition in Canadian banking. Journal of Money, Credit and Banking, v. 25, n. 1, p. 49-61, 1993.

. What drives bank competition? Some international evidence. In: CLAESSENS, Stijn; LAEVEN, Luc. Journal of Money, Credit and Banking, v. 36, n. 3, p. 585-92, 2004. Comment.

SILVA, T. L.; JORGE NETO, P. de M. Economia de escala e eficiência nos bancos brasileiros após o Plano Real. Estudos Econômicos, v. 32, n. 4, p. 577-619, 2002.

WOLFRAM, C. D. Measuring duopoly power in the British electricity spot market. American Economic Review, v. 89, n. 4, p. 805-826, 1999. 


\section{Appendix A}

Table A1 - Descriptive Statistics

\begin{tabular}{|c|c|c|c|c|c|}
\hline Variable Code & Obs & Mean & Std. Dev. & Min & Max \\
\hline$v 7$ & 2458 & $11,500,000$ & $33,700,000$ & 21,897 & $261,000,000$ \\
\hline$v 13$ & 2458 & $3,481,204$ & $10,500,000$ & 3.3042 & $109,000,000$ \\
\hline$v 14$ & 2458 & $-248,419$ & 809,059 & $-7,745,116$ & 0.0000 \\
\hline$v 17$ & 2458 & 222,831 & 849,331 & -2557.9310 & $14,400,000$ \\
\hline$v 18$ & 2458 & 411,815 & $1,488,009$ & 92.3231 & $14,700,000$ \\
\hline$p 7$ & 2458 & $10,500,000$ & $31,300,000$ & 669.0000 & $248,000,000$ \\
\hline$p 13$ & 2458 & $4,606,502$ & $16,000,000$ & 0.0000 & $138,000,000$ \\
\hline$p 18$ & 2458 & $1,381,056$ & $3,609,167$ & 0.0000 & $27,700,000$ \\
\hline$d 13$ & 2458 & $4,606,502$ & $16,000,000$ & 0.0000 & $138,000,000$ \\
\hline 17 & 2458 & 108,040 & 407,315 & 0.0000 & $3,953,364$ \\
\hline 18 & 2458 & $-118,770$ & 421,628 & $-4,937,046$ & 0.0000 \\
\hline 19 & 2458 & $-121,870$ & 388,150 & $-3,019,480$ & -110.2011 \\
\hline$l 10$ & 2458 & $-26,218$ & 84,270 & $-886,142$ & -8.0000 \\
\hline$l 12$ & 2458 & 91,272 & 384,675 & 0.0000 & $6,827,962$ \\
\hline$l 13$ & 2458 & $-84,824$ & 314,316 & $-4,542,411$ & 0.0000 \\
\hline$l 15$ & 2458 & 3,232 & 46,757 & $-573,807$ & 996,663 \\
\hline 120 & 2458 & 4,186 & 15,111 & 1.0000 & 109,756 \\
\hline$l 21$ & 2458 & 146 & 509 & 1.0000 & 4,008 \\
\hline$r 7$ & 2458 & 403,975 & $1,205,036$ & $-2,697$ & $11,000,000$ \\
\hline$r 8$ & 2458 & 304,117 & 915,436 & $-231,605$ & $11,100,000$ \\
\hline$r 9$ & 2458 & 375 & 186,007 & $-2,160,811$ & $1,773,772$ \\
\hline$r 10$ & 2458 & 35,850 & 225,978 & 0.0000 & $6,373,477$ \\
\hline$r 11$ & 2458 & 28,147 & 165,252 & $-242,481$ & $2,887,684$ \\
\hline$r 12$ & 2458 & $-321,752$ & 979,165 & $-10,700,000$ & 0.0000 \\
\hline$r 13$ & 2458 & $-108,423$ & 437,195 & $-8,399,907$ & 0.0000 \\
\hline$r 14$ & 2458 & $-31,984$ & 116,265 & $-1,871,072$ & 0.0000 \\
\hline$r 15$ & 2458 & $-3,480$ & 34,711 & $-1,295,229$ & 0.0000 \\
\hline$r 16$ & 2458 & $-56,520$ & 218,456 & $-2,923,509$ & 140,586 \\
\hline TOTAL $_{i t}$ & 2458 & 17,240 & 470.1988 & 16,395 & 18,075 \\
\hline$A G N_{i t}$ & 2458 & 0.0084 & 0.0293 & 0.0001 & 0.2233 \\
\hline$C R D_{i t}$ & 2458 & 34.2769 & 652.4069 & 0.0000 & 20,744 \\
\hline$W 1_{i t}$ & 2458 & 188 & 1,684 & 0.0000 & 43,725 \\
\hline$R D E P_{i t}$ & 2458 & 0.0518 & 0.0926 & 0.0002 & 2.3991 \\
\hline$W 3_{i t}$ & 2458 & 1.1783 & 10.1472 & 0.0009 & 463 \\
\hline$R T_{i t}$ & 2458 & 975,008 & $2,921,469$ & 916.4088 & $30,000,000$ \\
\hline$D E P S_{i t}$ & 2458 & $15,100,000$ & $47,000,000$ & 875 & $374,000,000$ \\
\hline$Y_{i t}$ & 2458 & 472,757 & 23,457 & 416,213 & 521,855 \\
\hline$Q_{i t}$ & 2458 & $11,500,000$ & $33,700,000$ & 21,897 & $261,000,000$ \\
\hline$P_{i t}$ & 2458 & 0.0893 & 0.0658 & 0.0052 & 1.7100 \\
\hline$Z_{i t}$ & 2458 & 1.4402 & 0.1941 & 1.1795 & 1.8979 \\
\hline$N P_{i t}$ & 2458 & 0.0226 & 0.0302 & 0.0000 & 0.5820 \\
\hline$Q U A L_{i t}$ & 2458 & 55.5622 & 67.3705 & 0.1111 & 530 \\
\hline$C_{i t}$ & 2458 & 873,839 & $2,662,558$ & 226.2021 & $29,200,000$ \\
\hline$C R E D S_{i t}$ & 2458 & $10,100,000$ & $28,800,000$ & 18,735 & $242,000,000$ \\
\hline$R C R E D_{i t}$ & 2458 & 0.1154 & 0.1185 & 0.0075 & 4.4769 \\
\hline$S H A R E_{i t}$ & 2458 & 0.0083 & 0.0240 & 0.0000 & 0.2072 \\
\hline$C R 3_{i t}$ & 2458 & 0.3992 & 0.0236 & 0.3451 & 0.4434 \\
\hline$A_{S S E M P}{ }_{i t}$ & 2458 & 44,991 & 352,693 & 378.2754 & $7,493,059$ \\
\hline$S U 1_{i t}$ & 2458 & 0.1258 & 0.1040 & 0.0000 & 1.2718 \\
\hline$S U 2_{i t}$ & 2458 & 0.1788 & 0.1371 & 0.0061 & 1.3067 \\
\hline
\end{tabular}


Table A2 - Estimated Conduct Paramaters

\begin{tabular}{|c|c|c|c|c|}
\hline & Model 1 & Model 2 & Model 3 & Model 4 \\
\hline$\beta_{1}^{L 1}$ & 0.091 & 0.093 & 0.061 & 0.077 \\
\hline $\operatorname{SE}\left(\beta_{1}^{L 1}\right)$ & 0.564 & 0.566 & 0.565 & 0.568 \\
\hline$\beta_{1}^{T 1}$ & 1.926 & 1.910 & 1.969 & 1.939 \\
\hline $\operatorname{SE}\left(\beta_{1}^{T 1}\right)$ & 0.675 & 0.677 & 0.676 & 0.680 \\
\hline$\beta_{2}^{L 1}$ & 0.002 & 0.002 & 0.002 & 0.002 \\
\hline$S E\left(\beta_{2}^{L 1}\right)$ & 0.010 & 0.010 & 0.010 & 0.010 \\
\hline$\beta_{2}^{T 1}$ & -0.028 & -0.028 & -0.028 & -0.028 \\
\hline$S E\left(\beta_{2}^{T 1}\right)$ & 0.011 & 0.011 & 0.011 & 0.011 \\
\hline$\beta_{3}^{L 1}$ & -0.003 & -0.003 & -0.003 & -0.003 \\
\hline$S E\left(\beta_{3}^{L 1}\right)$ & 0.002 & 0.002 & 0.002 & 0.002 \\
\hline$\beta_{3}^{T 1}$ & -0.005 & -0.005 & -0.005 & -0.005 \\
\hline $\operatorname{SE}\left(\beta_{3}^{T 1}\right)$ & 0.002 & 0.002 & 0.002 & 0.002 \\
\hline$\beta_{1}^{L 2}$ & -3.876 & -3.845 & -3.963 & -3.902 \\
\hline$S E\left(\beta_{1}^{L 2}\right)$ & 1.350 & 1.354 & 1.353 & 1.360 \\
\hline$\beta_{1}^{T 2}$ & -3.825 & -3.793 & -3.911 & -3.850 \\
\hline$S E\left(\beta_{1}^{T 2}\right)$ & 1.350 & 1.354 & 1.353 & 1.360 \\
\hline$\beta_{2}^{L 2}$ & 0.056 & 0.056 & 0.055 & 0.055 \\
\hline$S E\left(\beta_{2}^{L 2}\right)$ & 0.022 & 0.022 & 0.022 & 0.022 \\
\hline$\beta_{2}^{T 2}$ & 0.056 & 0.055 & 0.055 & 0.055 \\
\hline$S E\left(\beta_{2}^{T 2}\right)$ & 0.022 & 0.022 & 0.022 & 0.022 \\
\hline$\beta_{3}^{L 2}$ & 0.056 & 0.056 & 0.055 & 0.055 \\
\hline$S E\left(\beta_{3}^{L 2}\right)$ & 0.022 & 0.022 & 0.022 & 0.022 \\
\hline$\beta_{3}^{T 2}$ & 0.056 & 0.056 & 0.055 & 0.055 \\
\hline$S E\left(\beta_{3}^{T 2}\right)$ & 0.022 & 0.022 & 0.022 & 0.022 \\
\hline$\beta_{1}^{L 3}$ & -3.850 & -3.818 & -3.936 & -3.875 \\
\hline$S E\left(\beta_{1}^{L 3}\right)$ & 1.350 & 1.354 & 1.353 & 1.360 \\
\hline$\beta_{1}^{T 3}$ & -3.852 & -3.821 & -3.939 & -3.878 \\
\hline$S E\left(\beta_{1}^{T 3}\right)$ & 1.350 & 1.354 & 1.353 & 1.360 \\
\hline$\beta_{2}^{L 3}$ & 0.056 & 0.056 & 0.055 & 0.055 \\
\hline$S E\left(\beta_{2}^{L 3}\right)$ & 0.022 & 0.022 & 0.022 & 0.022 \\
\hline$\beta_{2}^{T 3}$ & 0.056 & 0.056 & 0.055 & 0.055 \\
\hline $\operatorname{SE}\left(\beta_{2}^{T 3}\right)$ & 0.022 & 0.022 & 0.022 & 0.022 \\
\hline$\beta_{3}^{L 3}$ & -3.852 & -3.821 & -3.939 & -3.878 \\
\hline$S E\left(\beta_{3}^{L 3}\right)$ & 1.350 & 1.354 & 1.353 & 1.360 \\
\hline$\beta_{3}^{T 3}$ & -3.852 & -3.821 & -3.939 & -3.878 \\
\hline $\operatorname{SE}\left(\beta_{3}^{T 3}\right)$ & 1.350 & 1.354 & 1.353 & 1.360 \\
\hline
\end{tabular}

